Article

\title{
Processes of Cracking and Crushing in Hybrid Fibre Reinforced High-Performance Concrete Slabs
}

\section{Piotr Smarzewski}

Department of Structural Engineering, Faculty of Civil Engineering and Architecture, Lublin University of Technology, 20-618 Lublin, Poland; p.smarzewski@pollub.pl; Tel.: +48-81-538-4394

Received: 23 November 2018; Accepted: 14 January 2019; Published: 18 January 2019

\begin{abstract}
This paper presents the experimental results obtained with the non-contact three-dimensional deformation measuring system-ARAMIS and finite element analysis performed using ANSYS of three slabs made of high-performance concrete (HPC) and hybrid (steel/ST and polypropylene/PP) fibre reinforced high-performance concrete (FRHPC). The research was performed on reinforced concrete (RC) slabs with a web mesh of $\phi 8 \mathrm{~mm}$ bars. All the slabs had an identical amount of steel bars and differed by the fibre volume content. The main objective of the research was to determine the impact of adding polypropylene and steel fibres on the carrying capacity and ductility of HPC slabs. Analysis of the results was conducted based on load-deflection curves, crack distribution, vertical displacements and strains. The research findings indicate that fibres may improve peak strength. The presence of PP and ST hybrid fibres in HPC restricted the propagation of cracks. The energy absorption capacity as well as the ductility index of HPC can be raised by adding hybrid fibres. A comparison of the experimental test results with the nonlinear finite element analysis is made. The numerical results concurred well with the experimental data. The research results indicate that non-contact measurement of deformation is an effective tool for monitoring crushing in FRHPC slabs.
\end{abstract}

Keywords: slab; high-performance concrete; reinforcement; steel fibres; polypropylene fibres; non-contact deformation measurements

\section{Introduction}

Concrete is a commonly used building material. In general it is weak in tension and brittle under low confining pressure. The demand for new concrete composites with improved qualities is due to the development of modern civil engineering construction [1-5]. Compared to traditional concrete, high-performance concrete (HPC) has better workability, mechanical properties and durability [6,7]. Fibres can be added to concrete to fabricate material with enhanced tensile strength, fracture toughness, ductility, resistance under fatigue and impact loading, as well as improved durability properties [8-14]. Fibres are categorized as metallic, polymeric and natural [15]. In general, for most structural purposes steel (ST) fibre is applied [16,17]. The thermoplastic polymer polypropylene has a wide range of applications that includes textiles, automotive components, reusable containers, loudspeakers or laboratory equipment. The polypropylene (PP) fibres added in HPC form channels for pressure to escape from the concrete, which prevents cracking and spalling [18]. The elastic modulus of synthetic fibres changes the properties of fibre reinforced high-performance concrete (FRHPC) when combined with different fibres. For structural concrete applications, other kinds of fibres are not commonly used. The fibres can bridge cracks as well as transfer stress across cracks. This effect is maximized when the fibres have deformed ends and are aligned in the direction of stress, perpendicular to the crack openings. The properties influenced by fibre hybridization of concrete with various types fibres has been studied by several researchers [8,19-21]. Hybrid fibres are used in order to control cracks at various curing ages, cracks of different sizes, in different areas of the concrete and at various loading 
stages [7]. An example is the use of steel or carbon fibres having a high modulus of elasticity which control large cracks and polypropylene fibres possessing a low modulus of elasticity which control the initiation of cracks as well as the propagation of small cracks [22]. Such fibre hybridization can increase the mechanical properties of concrete in a large range of crack openings.

Fairbaim et al. [23] presented an experimental and numerical analysis of slabs made of ultra-high-performance fibre reinforced concrete (UHPFRC). The UHPFRC slabs were tested until failure and modelled using the Finite Element Analysis (FEA) solver DIANA (acronym displacement analyser). The good correlation between the numerical and experimental load-deflection curve and similar crack patterns indicates that the applied methodology may by useful for simulating UHPFRC slab responses up to failure. Dancygier et al. [24] investigated the response of HPC slab samples to impact. The test specimens differed in the type and maximum size of aggregates, addition of steel fibres and micro-silica, as well as reinforcement details. The main findings show that design of HPC slabs to impact loads includes selecting the right type of aggregate with regard to its hardness and grain size. The study also showed that the main contribution of adding steel fibres to HPC is reduction of the damaged area of HPC slabs. Qiu [25] used three-dimensional (3-D) nonlinear finite element analysis to study multi-ribbed concrete slabs with varying volume frictions of steel fibres. The researcher reported that adding steel fibre to concrete has a better effect on reducing the deflection than increasing concrete strength and can improve the cracking load of the structure. Fike and Kodur [26] presented experimental and numerical studies were performed to evaluate the fire performance of floor systems composed unprotected steel beams and steel fibre reinforced concrete (SFRC) deck slabs. This results reported that the improved properties of SFRC slabs under fire, loading and restraint conditions can provide satisfactory fire resistance in steel beam-SFRC deck slabs without the need for external fire protection on the floor system. Kodur et al. [27,28] showed a 3-D nonlinear Finite Element (FE) model for evaluating the response of composite beam-slab assemblies subjected to a gravity and fire loading. The behaviour of structural assemblies exposed to different fire scenarios was modelled using ANSYS package. The finite element model was validated by comparing the predicted and measured response parameters of composite structures tested under fire conditions. The comparisons showed that the proposed model is capable of predicting the fire response of structural assemblies with good accuracy as well as that the composite action between the unprotected steel beam and steel fibre reinforced concrete slab significantly enhances the fire performance of composite structure. Almusallam et al. [29] studied the effect of hybrid fibres on the impact behaviour of reinforced normal-strength concrete and high-strength concrete slabs. The impact penetration tests revealed that owing to the hybrid fibres there is a smaller crater volume and the amount of spalling is reduced. Moreover the hybrid fibres halt crack distribution and curtail the size of the failure zone. A simple formulation was also proposed to predict the mass ejected from the front and the rear faces of the concrete slabs after the impact of the projectile fired from the air-gun system. Thiagarajan et al. [30] presented research on the response to explosive loads of high-strength concrete slabs, normal-strength concrete ones with double high-strength reinforcement and with conventional steel reinforcing bars. LS-DYNA program employing two material models for concrete was used to carry out numerical analysis. The numerical simulation results were compared to the experimental data in order determine the parameters of the materials. Mesh sensitivity and crack propagation investigations were also conducted.

The literature review shows that few works are available on the failure behaviour of high-performance concrete slabs reinforced with web mesh and hybrid-fibres (a mixture of steel and polypropylene fibres of different contents).

The aim of this paper is the experimental and finite element analysis of the ultimate behaviour of steel-polypropylene fibre reinforced high-performance concrete slabs. FRHPC slabs were studied with the 3-D deformation measuring system ARAMIS [31]. The finite element method package ANSYS was employed to perform numerical implementation of the model [32]. Numerical and graphical comparisons were made of the finite element modelling results and the experimental data. It was 
revealed that the upper limit of steel fibres contents needs to be reduced to ensure a suitable response of FRHPC slabs.

\section{Materials and Methods}

Table 1 presents the compositions and abbreviated names of the three concrete mixtures. Portland cement CEM I 52.5R (CEMEX, Chełm, Poland) tests were performed according to the PN-EN 197-1:2012 [33] and PN-B-19707:2013 standards [34]. The particle size distribution of quartz sand and granodiorite coarse aggregate was determined in accordance with the EN 933-1:2000 standard [35]. A highly efficient superplasticizer Glenium ${ }^{\circledR}$ SKY 591 (BASF, Myślenice, Poland) based on polycarboxylate ethers and having a density of $1.065 \mathrm{~g} / \mathrm{cm}^{3}$ at $20{ }^{\circ} \mathrm{C}$ was utilized to obtain a similar workability. The steel fibres BAUMIX ${ }^{\circledR}\left(\right.$ BAUTECH $^{\circledR}$, Piaseczno, Poland) possess the following properties: density $7.8 \mathrm{~g} / \mathrm{cm}^{3}$, length $50 \mathrm{~mm}$, diameter $1 \mathrm{~mm}$, modulus of elasticity $200 \mathrm{GPa}$, tensile strength $1100 \mathrm{MPa}$, while the polypropylene fibres BAUCON ${ }^{\circledR}\left(\right.$ BAUTECH$^{\circledR}$, Piaseczno, Poland) are characterized by: density $0.9 \mathrm{~g} / \mathrm{cm}^{3}$, length $12 \mathrm{~mm}$, diameter $25 \mu \mathrm{m}$, modulus of elasticity $3.5 \mathrm{GPa}$, tensile strength $350 \mathrm{MPa}$. These fibres are shown in Figure 1.

Table 1. Concrete compositions.

\begin{tabular}{ccccc}
\hline Component & Unit & S1 & S2 & S3 \\
\hline Cement CEM I 52.5R & $\mathrm{kg} / \mathrm{m}^{3}$ & 596 & 596 & 596 \\
Silica fume & $\mathrm{kg} / \mathrm{m}^{3}$ & 59.6 & 59.6 & 59.6 \\
Quartz sand 0.05/2 $\mathrm{mm}$ & $\mathrm{kg} / \mathrm{m}^{3}$ & 500 & 500 & 500 \\
Granodiorite 2/8 mm & $\mathrm{kg} / \mathrm{m}^{3}$ & 990 & 990 & 990 \\
Water & $1 / \mathrm{m}^{3}$ & 196 & 196 & 196 \\
Superplasticizer & $1 / \mathrm{m}^{3}$ & 20 & 20 & 20 \\
Steel/ST fibres & $\mathrm{kg} / \mathrm{m}^{3}$ & - & 39 & 78 \\
& $\%$ & - & 0.5 & 1 \\
Polypropylene/PP fibres & $\mathrm{kg} / \mathrm{m}^{3}$ & - & 0.5 & 0.5 \\
& $\%$ & - & 0.06 & 0.06 \\
Water/Binder (W/B) ratio & - & 0.3 & 0.3 & 0.3 \\
\hline
\end{tabular}

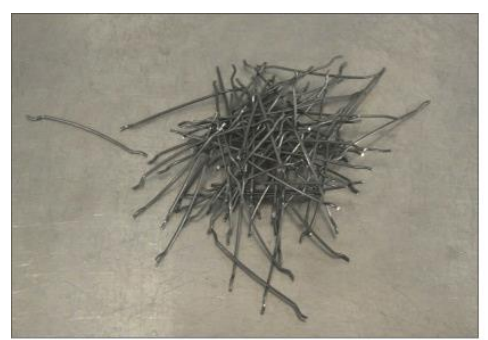

(a)

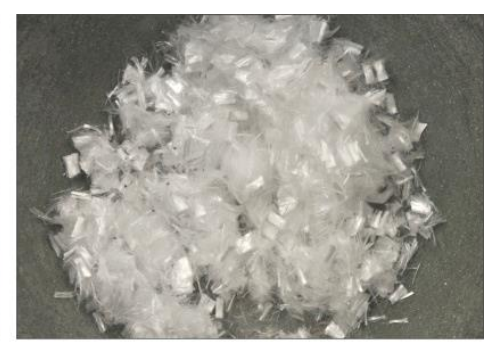

(b)

Figure 1. (a) Hooked-end steel fibres; (b) Polypropylene fibres.

The mixtures were prepared using a typical concrete mixer. Mixing commenced with homogenization of the granodiorite and quartz sand with a half of the water. Next, the cement, silica fume, the remaining water and finally the superplasticizer were added. After thoroughly mixing the components the steel and polypropylene fibres were added to the S2 and S3 mixtures by hand to obtain homogeneous and workable consistencies.

Three concrete slabs $1000 \mathrm{~mm} \times 800 \mathrm{~mm} \times 60 \mathrm{~mm}$ were prepared with the S1, S2 and S3 mixture compositions. The moulds for the slabs were made of plywood. The web meshes of the slabs consisted of $\phi 8 \mathrm{~mm}$ deformed bars (see Figure 2a). Furthermore six cubes and six prismatic samples were made form the $\mathrm{S} 1$ mixture composition. The concrete mixtures were poured into moulds coated with an anti-adhesive substance and then were compacted on a vibrating table. Before removing the samples 
from the moulds they were stored for $24 \mathrm{~h}$ at a temperature of about $23^{\circ} \mathrm{C}$. Curing of the samples took placed for 7 days in a water tank and then up to 28 days in laboratory conditions.

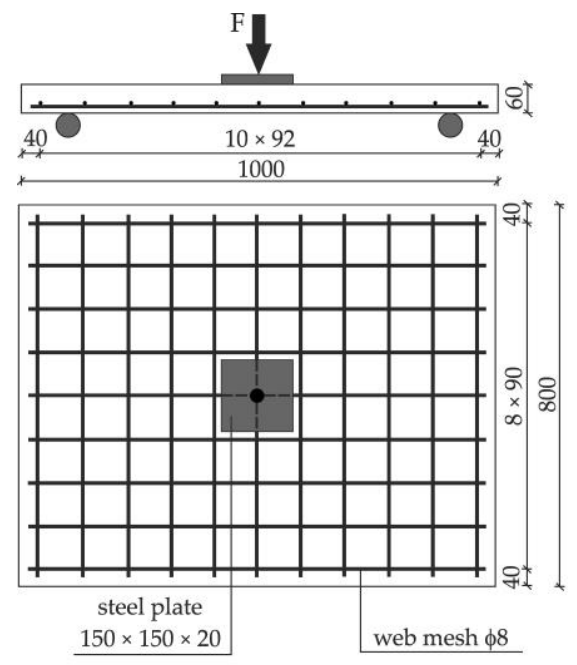

(a)

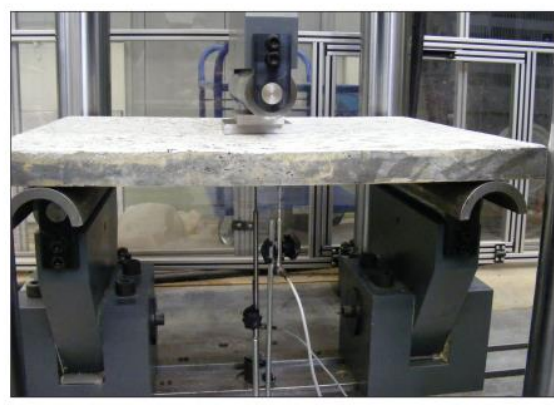

(b)

Figure 2. (a) Dimensions and reinforcement arrangement of test slabs (unit in $\mathrm{mm}$ ); (b) Test set-up.

At 28 days, cubes $150 \mathrm{~mm} \times 150 \mathrm{~mm} \times 150 \mathrm{~mm}$ were used to determine the compressive and tensile splitting strengths, on the basis of PN-EN 12390-3:2011 [36] and PN-EN 12390-6:2011 [37]. A 3 MN capacity servo-hydraulic closed-loop testing machine (walter + bai ag Testing Machines, Löhningen, Switzerland) was used. At 28 days, four-point bending tests were conducted on prismatic samples $500 \mathrm{~mm} \times 100 \mathrm{~mm} \times 100 \mathrm{~mm}$ on an MTS 809 axial/torsional testing system machine (MTS, Eden Prairie, MN, USA), according to PN-EN 12390-5:2011 [38]. The spacing of the supports was $300 \mathrm{~mm}$. Cylinders $\phi 150 \mathrm{~mm} \times 300 \mathrm{~mm}$ were produced to test the modulus of elasticity in accordance with ASTM C469/C469M-14 [39]. The concrete and fibre reinforced concrete mechanical properties are given in Table 2.

Table 2. Concrete properties.

\begin{tabular}{ccccc}
\hline $\begin{array}{c}\text { Slab } \\
\text { Denotation }\end{array}$ & $\begin{array}{c}\text { Compressive } \\
\text { Strength (MPa) }\end{array}$ & $\begin{array}{c}\text { Splitting Tensile } \\
\text { Strength } \mathbf{( M P a )}\end{array}$ & $\begin{array}{c}\text { Flexural Tensile } \\
\text { Strength (MPa) }\end{array}$ & $\begin{array}{c}\text { Modulus of } \\
\text { Elasticity (GPa) }\end{array}$ \\
\hline S1 & 99.4 & 5.0 & 8.2 & 38.74 \\
S2 & 107.2 & 10.2 & 9.1 & 38.93 \\
S3 & 111.0 & 11.0 & 9.4 & 39.42 \\
\hline
\end{tabular}

The mechanical properties of the steel bars were verified during the tensile tests. Investigations of steel bars $8 \mathrm{~mm}$ in diameter and $300 \mathrm{~mm}$ in length were conducted by means of an MTS 810 testing system machine (MTS, Eden Prairie, MN, USA) with a load range 0-100 kN. The bars were fixed with special holding jaws which prevented potential sliding and incorrect measurements. During the tensile test the current load, bar extension and crosswise relocation were measured. On the basis of these results yield stress $f_{y k}=567 \mathrm{MPa}$, tensile strength $f_{t k}=644 \mathrm{MPa}$ and modulus of elasticity $E_{s}=206 \mathrm{GPa}$ were calculated.

The tests on the slabs were conducted on a hydraulic press (Zwick/Roell, Wrocław, Poland) (Figure $2 b$ ). The effective span-effective depth ratio for single-span solid slabs is 17.4. The effective span of the slab is the distance between the centreline of the supports and was taken to be $0.8 \mathrm{~m}$. The reinforcement ratio was constant for all slabs of $1.2 \%$. The machine can achieve a maximum load of $3 \mathrm{MN}$ under compression. The slabs were loaded at a constant increment of press piston displacement. The test was conducted until the layers in the loaded area of the concrete slab were finally crushed and in the tensed area the cracks were over $5 \mathrm{~mm}$. 
Along with load capacity tests, 3-D deformation measurements were made by the ARAMIS system (GOM mbH, Braunschweig, Germany) (Figure 3a). On the basis of photographs taken by digital cameras (GOM mbH, Braunschweig, Germany), the system recognised the surface of the measured object. Each pixel in the photograph had its coordinates. The system recorded, computed and analysed the deformation states. The strains can be record in the range from $0.01 \%$ up to a few hundred percent [31].

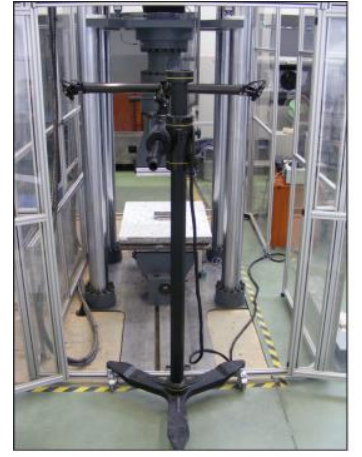

(a)

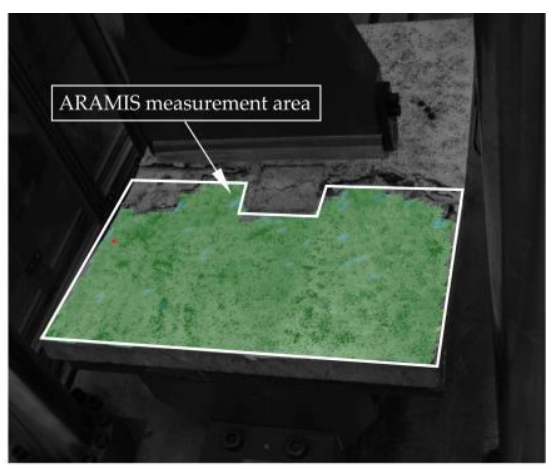

(b)

Figure 3. (a) Non-contact 3-D deformation measurement system; (b) Measurement area of top surface of slab.

The top surface of the slabs were whitewashed and randomly covered with black paint. Such a procedure is necessary to calculate heterogeneous materials without sufficient characteristics. In next step, the measurement system was calibrated. On the basis of the angle between the axes of the cameras, three-dimensional coordinates were defined from the two-dimensional coordinates from the left and right cameras. The recording speed and measurement area were assumed (Figure 3b).

The coordinates, displacements and strains are determined with the optical measurement technique only on the surface of the objects. Therefore, only local strains that were tangential to the surface were calculated. The stretch ratio is the relative elongation of a line element and is defined below

$$
\lambda=\lim _{l \rightarrow 0}\left(\frac{l+\Delta l}{l}\right)
$$

Strain $\varepsilon$ was defined as a function of stretch ratio $\lambda$. The following known expressions are commonly used strain measures: technical strain as $\varepsilon^{T}=\lambda-1$, true (logarithmic) strain as $\varepsilon^{L}=\varphi=\ln (\lambda)$, as well as Green's strain as $\varepsilon^{G}=\frac{1}{2}\left(\lambda^{2}-1\right)$.

Deformation gradient tensor $\mathbf{F}$ indicates surface element deformation quantitatively. $\mathbf{F}$ transforms line element $d \mathbf{X}$ into line element $d \mathbf{x}$. In both circumstances $d \mathbf{x}$ connects the same material coordinates. Hence, $\mathbf{F}$ is defined in the following way

$$
d \mathbf{x}=\mathbf{F} d \mathbf{X}
$$

The stretch and rotation were modelled using one matrix and $\mathbf{F}$ was split into a pure rotation tensor and a pure stretch tensor. The matrix was decomposed into left stretch tensor $\mathbf{V}$ and rotation $\mathbf{R}$ or right stretch tensor $\mathbf{U}$ and rotation $\mathbf{R}$

$$
\mathbf{F}=\mathbf{V R}, \mathbf{F}=\mathbf{U R}
$$

Stretch tensor $\mathbf{U}$ was calculated from Cauchy strain tensor $\mathbf{C}$

$$
\mathbf{U}=\sqrt{\mathbf{C}}
$$


By means of the formula below, strains $\varepsilon_{x}, \varepsilon_{y}, \varepsilon_{x y}$ can be read from stretch tensor $\mathbf{U}$

$$
\mathbf{U}=\left(\begin{array}{cc}
1+e_{x} & e_{x y} \\
e_{x y} & 1+e_{y}
\end{array}\right)
$$

Strain measures $\varepsilon_{x}, \varepsilon_{y}$ were defined as dependent on the coordinate system. By calculating the major and minor strains, this disadvantage was eliminated. Symmetrical matrix $\mathbf{U}$ was transformed and $\lambda_{1}$ and $\lambda_{2}$ were computed from the formulation

$$
\lambda_{1,2}=1 \pm \sqrt{\left(\frac{\varepsilon_{x}+\varepsilon_{y}}{2}\right)^{2}-\left(\varepsilon_{x} \varepsilon_{y}-\varepsilon_{x y}^{2}\right)}+\frac{\varepsilon_{x}+\varepsilon_{y}}{2}
$$

The effective strains outcomes are as follows

$$
\varphi_{V}=\sqrt{\frac{2}{3}\left(\varphi_{1}^{2}+\varphi_{2}^{2}+\varphi_{3}^{2}\right)}
$$

As $\varphi_{3}$ is included, if the volume constancy is valid, then the effective strain is also valid. The technical strains were calculated based on the true (logarithmic) strains with subsequent conversion $\varepsilon=e^{\varphi}[31]$.

\section{Model Formulation}

\subsection{General Description}

ANSYS software (ANSYS, Inc. Release 14.5, Canonsburg, PA, USA, 2012) was employed to carry out finite element analysis. The HPC and the steel-polypropylene FRHPC were modelled by means of SOLID65 eight-node solid elements. These elements are defined by the isotropic HPC properties and two types of fibres. The fibre specifications included the volume ratio calculated as the fibre volume divided by the total slab volume, as well as the fibre reinforcement orientation angle. The finite element is capable of describing the cracking in tension zone by the smeared crack formulation and crushing in the compression region by the plasticity algorithm. LINK180 3-D spar elements, which allow elastic-plastic response of the steel bars, were used to model the steel web mesh. The steel plates located at the supports and loaded area were modelled by SOLID185 eight-node solid brick elements and were added at these locations in order to avoid stress concentration problems and to prevent localized crushing of concrete elements near the supporting points and load application locations. This provided a more even stress distribution over the support area [32].

The failure surfaces of concrete under due to static and dynamic loading were described in References [40-46]. In this paper, the triaxial failure surface of unconfined plain concrete was applied [40]. Figure 4 illustrates the triaxial failure surface divided into hydrostatic and deviatoric sections.

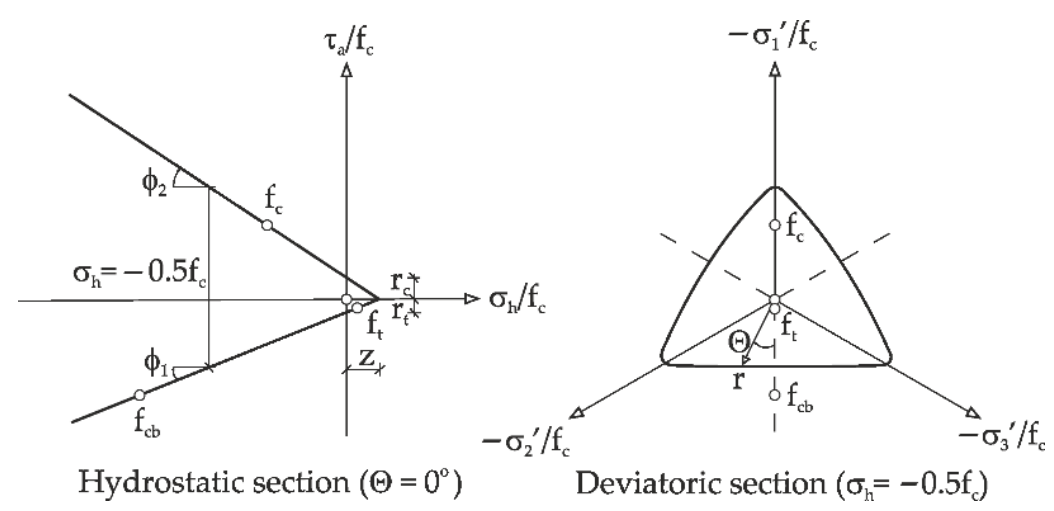

Figure 4. Three parameter model [40]. 
Polar coordinates $r$ and $\theta$ describe the strain deviator, where $r$ is a radial vector locate the failure surface for any $\theta$ angle from the range $0 \leq \theta \leq 60^{\circ}$. Equation (8) below defines the failure surface

$$
\frac{1}{z} \frac{\sigma_{h}}{f_{c}}+\frac{1}{r(\theta)} \frac{\tau_{a}}{f_{c}}=1
$$

where $\sigma_{h}, \tau_{a}$ are the mean normal or tangent stress, $z$ is the surface vertex, $f_{c}$ is the uniaxial compressive strength.

$\phi_{1}$ and $\phi_{2}$ define the opening angles of the hydrostatic cone. Based on uniaxial compressive strength $f_{c}$, the uniaxial tensile strength $f_{t}$ and biaxial compressive strength $f_{c b}$, the failure surface parameters, $z$ and $r$ are identified. These three strengths were obtained from experimental tests.

\subsection{Material Properties}

The SOLID65 element requires linear isotropic and multilinear isotropic material properties. ACI 363 [47] was referred to in order to calculate the HPC tensile strength and modulus of elasticity.

$$
\begin{gathered}
f_{t}=0.54 \sqrt{f_{c}} \\
E_{c}=3.32 \sqrt{f_{c}}+6.9
\end{gathered}
$$

The compressive uniaxial stress-strain relationship shown in Figure 5a was used for the HPC model. This relationship is the combination of constitutive models Desayi and Krishnan [48] and Stolarski [44]. Linear function is assumed to $30 \%$ of the ultimate uniaxial compressive strength $f_{c}$. Then concrete is behave as elastic-plastic material with hardening up to $f_{c}$. After reaching ultimate compressive strength the concrete is softened to value $0.8 f_{c}$ corresponding to ultimate strain $\varepsilon_{u}$. Kamińska [49] reported that high-strength concrete was crushed when strains measured in the full size beams reached two fold higher values than strains in the small specimens. For this reason, the higher compressive strains $\varepsilon_{0}=0.006$ at $f_{c}$ and $\varepsilon_{u}=0.012$ at $0.8 f_{c}$ are adopted in the HPC model. This compressive stress-strain relation was applied to help obtain convergence of the nonlinear solution [50-52]. In the stages of concrete cracking or crushing, the stiffness matrix is adapted to the failure mode. The shear transfer coefficient for open crack $\beta_{t}$ is introduced as a multiplier to reduce the shear transfer that cause slip in the plane perpendicular to the crack surface.

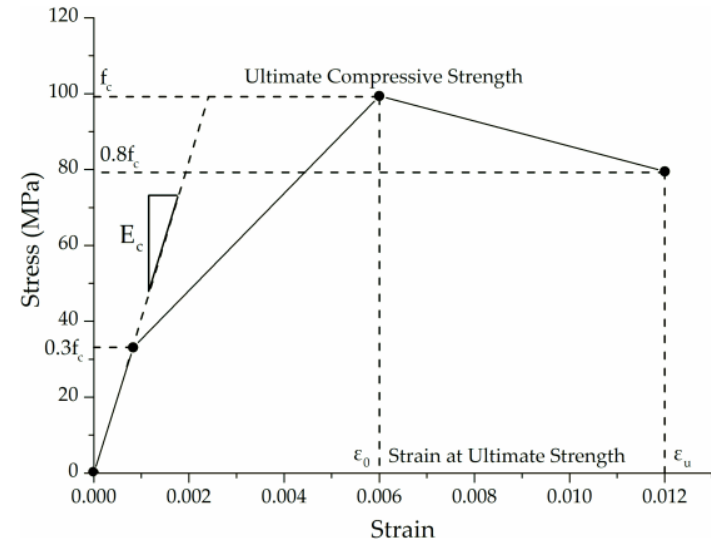

(a)

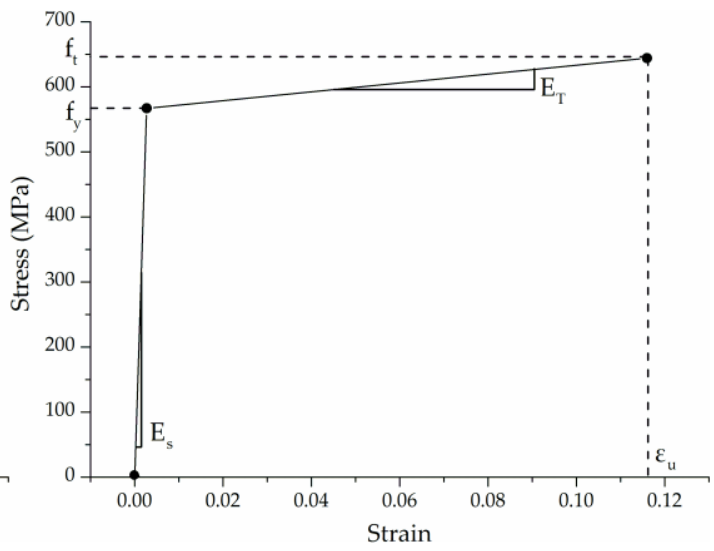

(b)

Figure 5. Uniaxial stress-strain curves for (a) compressive concrete; (b) tensile steel bar.

The steel rebars in the slabs were constructed as a typical mesh. By means of the uniaxial tensile test the elastic modulus and yield stress of the steel rebars were obtained. These values were used to create the FE model of the reinforcement. The steel rebars were treated as elastic-plastic material with linear hardening as well as with identical characteristics in tension and compression. The rebar 
stress-strain curve is shown in Figure 5b. For the steel plates located at the support and loaded zones, the linear elastic model was assumed.

Slabs S2 and S3 were reinforced with randomly distributed steel and polypropylene fibres represented as a smeared layers in the concrete element. It is assumed that polypropylene fibres behave isotropically due to their low aspect ratio. Therefore, PP fibre properties applied in the finite element model are the modulus of elasticity and Poisson's ratio. Steel fibre is assumed to be bilinear isotropic material. Bilinear isotropic model is based on the von Mises failure criteria and requires the yield stress as well as the hardening modulus of the steel fibre to be defined. The properties of the HPC, steel rebar, steel and polypropylene fibre are listed in Table 3.

Table 3. Summary of material properties.

\begin{tabular}{|c|c|c|c|c|c|c|c|c|c|c|c|c|c|c|}
\hline \multicolumn{5}{|c|}{ High Performance Concrete } & \multicolumn{4}{|c|}{ Steel Rebar } & \multicolumn{4}{|c|}{ ST Fibre } & \multicolumn{2}{|c|}{ PP Fibre } \\
\hline $\begin{array}{c}E_{c} \\
(\mathrm{GPa})\end{array}$ & $\begin{array}{c}f_{c} \\
(\mathrm{MPa})\end{array}$ & $\begin{array}{c}f_{t} \\
(\mathrm{MPa})\end{array}$ & $v_{c}$ & $\beta_{t}$ & $\begin{array}{c}E_{S} \\
(\mathrm{GPa})\end{array}$ & $\begin{array}{c}E_{T} \\
(\mathrm{GPa})\end{array}$ & $\begin{array}{c}f_{y} \\
(\mathrm{MPa})\end{array}$ & $v_{s}$ & $\begin{array}{c}E_{s f} \\
(\mathrm{GPa})\end{array}$ & $\begin{array}{c}f_{y} \\
(\mathrm{MPa})\end{array}$ & $\begin{array}{c}f_{t} \\
(\mathrm{MPa})\end{array}$ & $v_{s f}$ & $\begin{array}{c}E_{p f} \\
(\mathrm{GPa})\end{array}$ & $v_{p f}$ \\
\hline 40 & 99.4 & 5.38 & 0.15 & 0.1 & 206 & 680 & 567 & 0.3 & 200 & 660 & 1100 & 0.3 & 3.5 & 0.25 \\
\hline
\end{tabular}

\subsection{Geometry and Meshing}

Selection of finite element size is an important factor in the finite element analysis of reinforced concrete structures. Bažant and Cedolin [53] reported that the smallest concrete element dimension in an FE model is controlled by the maximum size of the coarse aggregate used. The choice of these dimensions was based on preliminary studies in which different finite element sizes were used. The mesh employed in this study provides a good balance between the numerical accuracy of results and the computational time required.

The full-size of the slab is $1000 \mathrm{~mm} \times 800 \mathrm{~mm} \times 60 \mathrm{~mm}$, while between the two supports the span measured $800 \mathrm{~mm}$. The full-size slab was used for finite element modelling of the volume. The flexural steel reinforcement was created using the 534 LINK180 elements. Figure 6a shows that the rebars share the same nodes at their intersection points. In order to receive satisfactory results for the SOLID65 elements, using a rectangular mesh is recommended [32]. Figure $6 \mathrm{~b}$ presents the overall mesh representing the concrete volume. Between the nodes generated by the concrete volume mesh were created link elements, thus eliminating the need for mesh of the rebar. However, the mesh attributes were established before creating each reinforcement section. 2496 SOLID65 elements were selected for the slab model. Each element is a prism $31.2 \mathrm{~mm} \times 31 \mathrm{~mm} \times 20 \mathrm{~mm}$. The elements and nodes of the steel plates at the loading point and the supports are consistent with the nodes and elements of the concrete slab finite elements. A perfect bond between the materials is assumed, with the reinforcement connected to the concrete mesh nodes. Hence, the concrete and the reinforcement meshes occupy the same nodes, thus the concrete shares the same areas as the rebars. A disadvantage of this model is the fact that the rebar volume is not removed from the concrete volume and the location of the reinforcement both restrict the concrete mesh. The force was applied across the entire centreline at each node on the steel plate. The supports were modelled as a rollers, which allow the slab to rotate. The nodes located in the centre of the support plate were assigned constraint in the $\mathrm{X}$ and $\mathrm{Z}$ directions. Figure $6 \mathrm{c}$ illustrates the force applied along the whole loading plate centreline. 


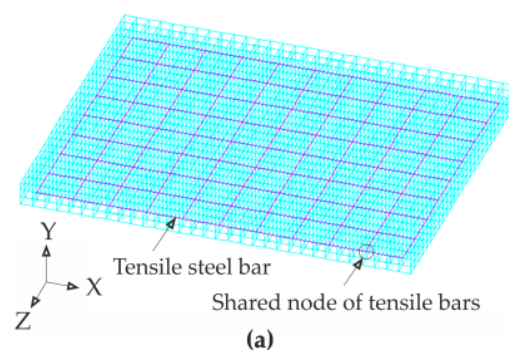

(a)

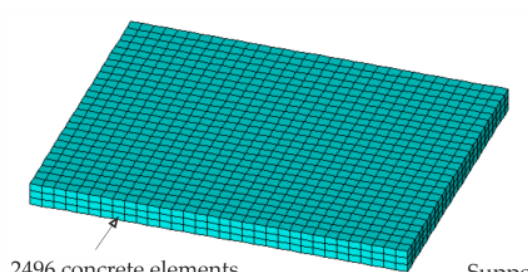

(b)

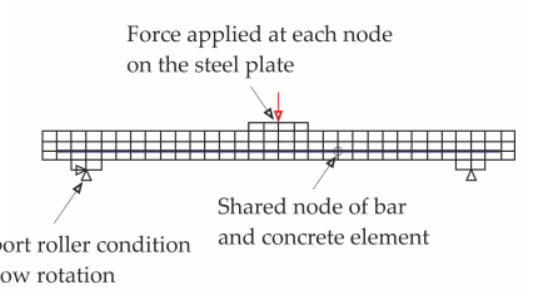

(c)

Figure 6. (a) Reinforcement configuration; (b) slab finite element mesh; (c) boundary conditions.

\subsection{Nonlinear Solution}

The total load applied on a slab model is separated into load steps in FE nonlinear analysis. After each incremental solution finishes and before proceeding to the subsequent load increment, the stiffness matrix is regulated to reflect nonlinear changes in structural stiffness [54-56]. Updating of the model stiffness is made by means of the Newton-Raphson equilibrium iterations. This approach estimates the difference between the restoring forces and applied loads, that is, the out-of-balance load vector. Should the convergence criteria not be satisfied, the out-of-balance load vector is assessed once again, then the stiffness matrix is updated and finally the solution is performed. The iterative procedure carries on to the moment the results converge. The convergence criteria is based on displacement for reinforced concrete solid elements. It was found that the convergence of solutions for the default setting of the convergence tolerance limits was difficult to achieve owning to the nonlinear response of reinforced concrete. Therefore, to achieve convergence of solutions the default tolerance limits were increased to a maximum of five times ( $5 \%$ for displacement checking).

\section{Results and Discussion}

\subsection{Load-Deflection Response}

Figure 7 depicts the plots of the test slabs load-deflection responses. The differences in deflection with load are almost linear until the first flexural macrocracks appeared. Reduced stiffness of the slabs at upper deflection was observed as more cracks developed. Furthermore, the fibres had an influence on the ultimate deflection of the slabs. A decreases in the ultimate deflection and peak load were detected when the fibre content was higher. Table 4 presents the load-deflection test results. The first macrocrack was detected at cracking load. The yielding load was calculated from the load-deflection response as the point corresponding to the deflection at the intersection between the secant stiffness at two-thirds of the peak load and the line passed through the peak load [57]. The failure load was calculates as 0.8 of the peak load according to [58].

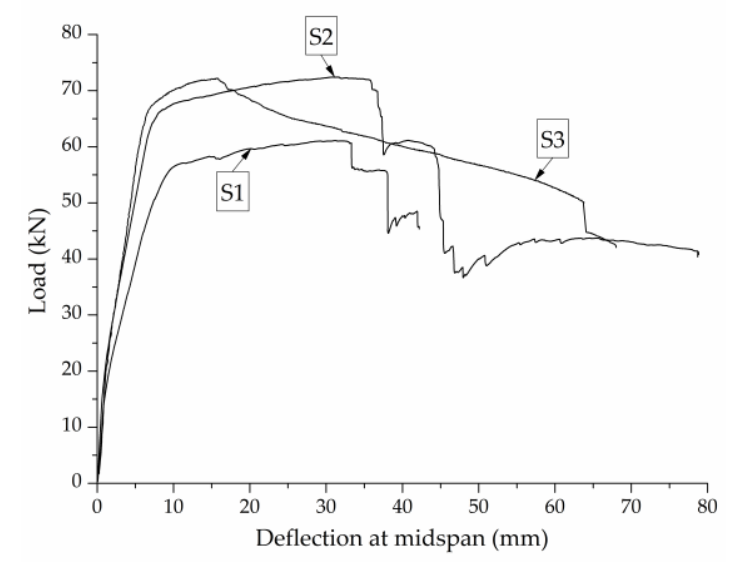

Figure 7. Load-deflection responses for experimental slabs. 
Table 4. Load and deflection response results for slabs.

\begin{tabular}{|c|c|c|c|c|c|c|c|c|c|}
\hline \multirow{2}{*}{$\begin{array}{c}\text { Slab } \\
\text { Denotation }\end{array}$} & \multirow{2}{*}{$\begin{array}{c}\text { Fibre Volume } \\
\text { Content }(\%)\end{array}$} & \multicolumn{2}{|c|}{ Cracking } & \multicolumn{2}{|c|}{ Yielding } & \multicolumn{2}{|c|}{ Peak } & \multicolumn{2}{|c|}{ Failure } \\
\hline & & $\begin{array}{l}\text { Load } \\
\text { (kN) }\end{array}$ & $\begin{array}{l}\text { Deflection } \\
(\mathrm{mm})\end{array}$ & $\begin{array}{l}\text { Load } \\
\text { (kN) }\end{array}$ & $\begin{array}{l}\text { Deflection } \\
(\mathrm{mm})\end{array}$ & $\begin{array}{l}\text { Load } \\
\text { (kN) }\end{array}$ & $\begin{array}{l}\text { Deflection } \\
(\mathrm{mm})\end{array}$ & $\begin{array}{l}\text { Load } \\
\text { (kN) }\end{array}$ & $\begin{array}{l}\text { Deflection } \\
(\mathrm{mm})\end{array}$ \\
\hline S1 & - & 14.3 & 0.9 & 52.0 & 8.0 & 61.1 & 31.2 & 48.9 & 38.1 \\
\hline S2 & $0.5 \mathrm{ST}+0.06 \mathrm{PP}$ & 15.9 & 0.8 & 63.8 & 7.1 & 72.4 & 31.5 & 57.9 & 44.5 \\
\hline S3 & $1 \mathrm{ST}+0.06 \mathrm{PP}$ & 18.1 & 0.9 & 61.2 & 6.4 & 72.2 & 15.6 & 57.8 & 46.8 \\
\hline
\end{tabular}

Slab S3 had a two-fold higher content of steel fibres in comparison with slab S2. Nevertheless, the first one had a lower ultimate deflection by about $14 \%$. Although, mixture S3 had relatively good workability, applying higher fibre quantities results in a clustering and saturation of the fibres, which tend to become entangled and create a porous and more fragile HPC matrix. This suggests that a maximum fibre volume content for each fibre type exists, in combination with the amount of aggregate and the corresponding granular composition and that a further increase in the fibre content cannot lead to the creation of a stable and homogeneous mixture. In this study a $1 \mathrm{vol} . \%$ addition of $50 \mathrm{~mm}$ length steel fibres results in grouping and clustering of the fibres. This phenomenon was confirmed by the microstructure observation of the transition zone of the PP fibres and the concrete matrix by scanning electron microscope (SEM, FEI Quanta FEG 250, Hillsboro, OR, USA) after mechanical tests of the slabs, Figure 8.

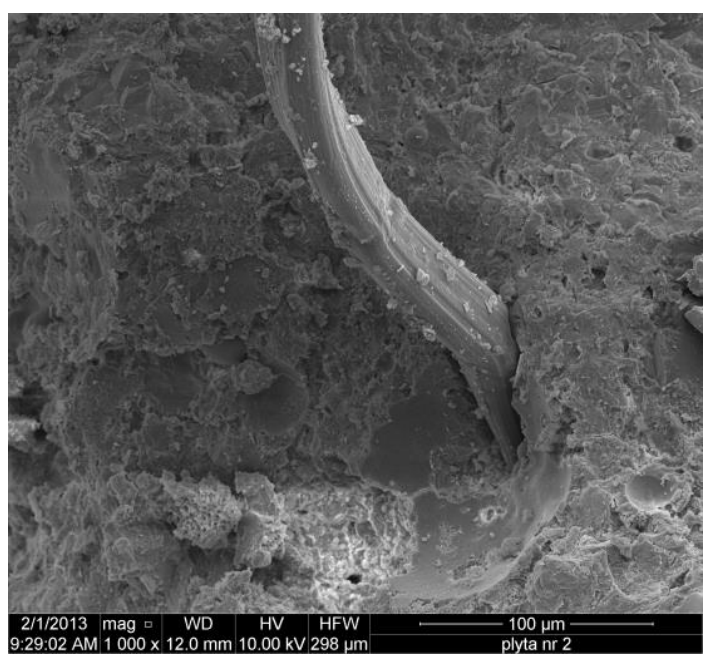

(a)

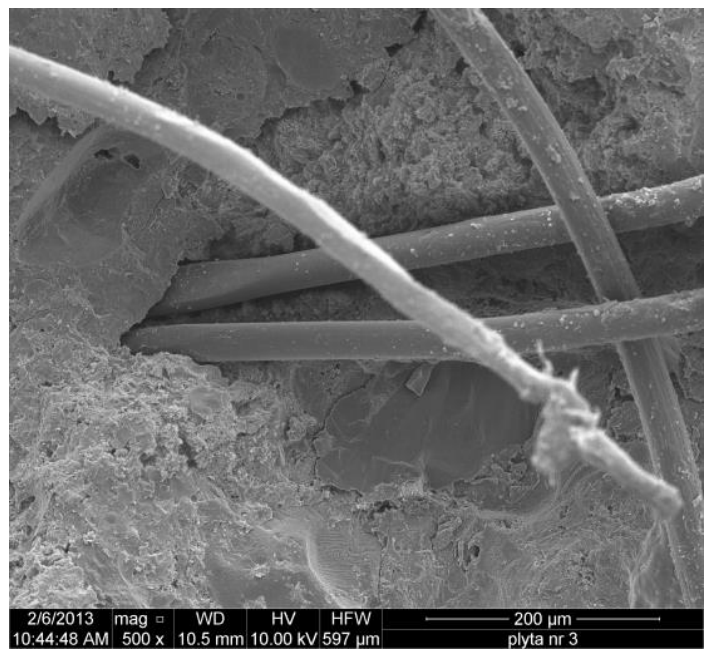

(b)

Figure 8. Scanning electron microscope images of polypropylene (PP) fibre in slab (a) S2; (b) S3.

Moreover, alignment of the fibres may not occur in the direction of the main tensile stress. Some researchers have investigated the influence of fibre orientation on the flexural performance of rectangular slabs of ultra-high performance fibre reinforced concrete produced with different casting-flow methods $[59,60]$. It has been observed that poor flexural performance occurs when the fibres are aligned perpendicular to the beam length [59]. In centrally poured concrete, the fibres were situated parallel to the flow direction and the slabs had not only much smaller load carrying capacities but also exhibited deflection softening behaviour [60].

\subsection{Cracking Processes and Failure Modes}

Figure 9 shows the crack propagation in different slabs at the load of $57 \mathrm{kN}$ and at the final load stage, respectively. The first flexural crack was initiated at early stage of loading at the midspan of all the slab elements and then propagated as the applied load increased. Cracks propagated parallel to the bottom reinforcement steel bars perpendicular to the effective span of the slab. It should be noted that the cracking load of slabs S2, S3 was raised by increasing the volume content of hybrid 
fibres. With the increase in load, cracks became wider and propagated in diagonal directions. In the meantime, more cracks occurred and propagated in the similar way as the earlier cracks. The number and width of cracks decreased with a higher fibre content. Addition of hybrid fibres improved the ductility as the fibres in the HPC matrix formed a closed network, which hindered the formation of crack and its propagation. At further loading steps, spalling in the top surface of the concrete slabs was observed. Slab S3 had a different crack pattern at the last load step. During the test only the first crack significantly increased its width. Even during the crack growth, the steel fibres in the concrete bridged the crack and prevented its further propagation. At the last loading step, small radial cracks appeared along the length of the main crack (Figure 9b).

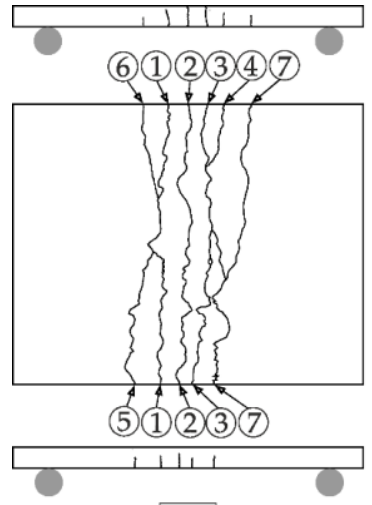

S1

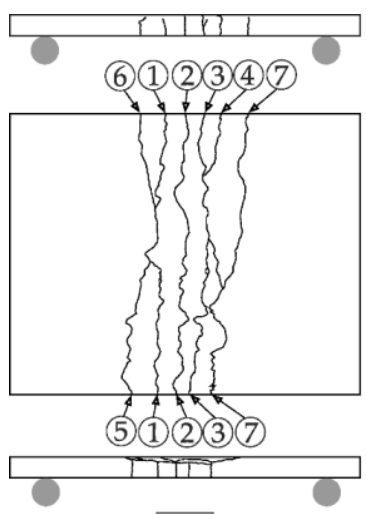

S1

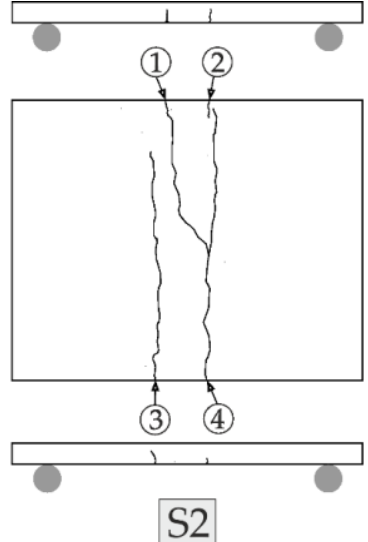

(a)

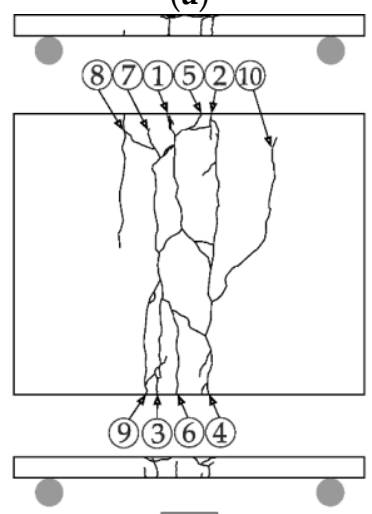

S2
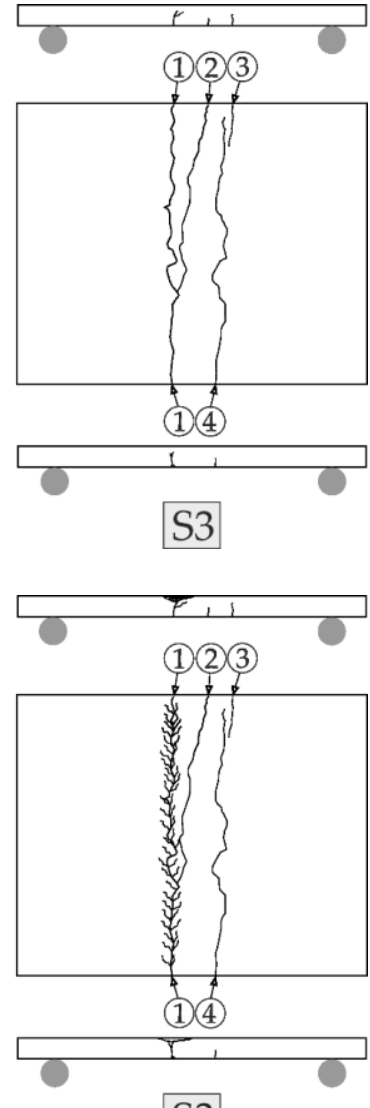

S3

(b)

Figure 9. Experimental crack distributions on slab bottom and side surfaces: (a) at load of $57 \mathrm{kN}$; (b) at last load.

The slabs exhibited three distinct modes of failure as shown in Figure 10. Cracks propagated in a larger zone at the midspan of slab S1 without fibres/with the steel web mesh. It can be noticed that rapid concrete spalling appeared in the compression layer. Slab S2 with the $0.5 \%$ ST fibre content and $0.06 \%$ PP fibre content had more cracks of a smaller width than slabs S1 and S3. Both fibre reinforced slabs showed relatively mild crushing of the concrete in the compression layer limited by the PP fibres. The concrete failure zone was the smallest in slab S3 with the 1\% ST fibre content. The smallest number of cracks were formed in this case and only the first crack significantly increased its width. 

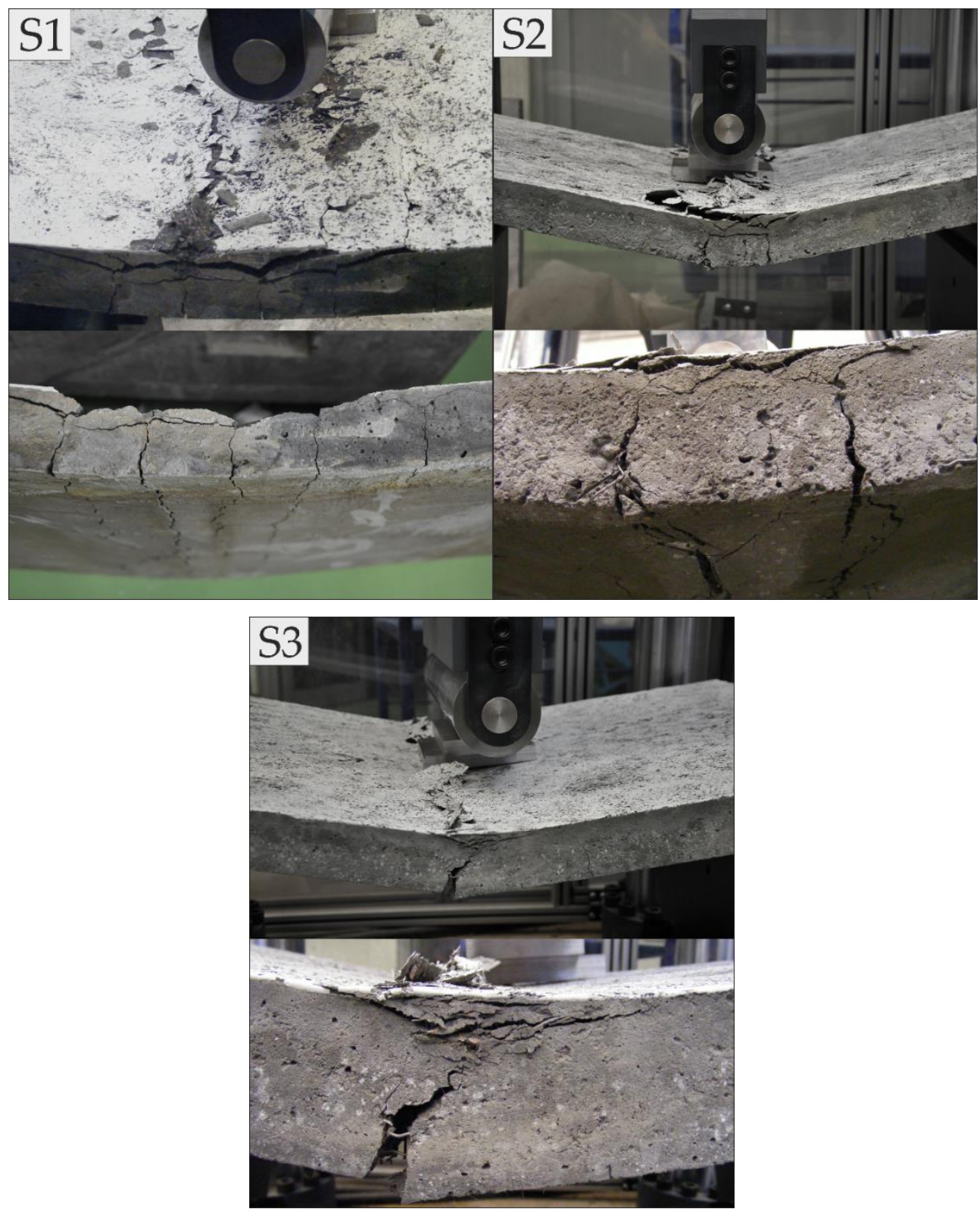

Figure 10. Failure modes.

\subsection{Crushing Processes}

The results of strains at the peak and last load step for the measurement areas of the slab top surfaces obtained in ARAMIS software (v6.3, GOM mbH, Braunschweig, Germany, 2011) are presented in Figure 11.

Slab S1 without fibres failed the earliest. Its vertical displacement at peak load reached the value of $31.2 \mathrm{~mm}$. The maximum vertical displacements ranging from 25 to $31.2 \mathrm{~mm}$ are located at the midspan of slab S1 for a width of $200 \mathrm{~mm}$. The maximum strain value at the top surface of slab S1 was significant and exceeded 3\%. It was related to local concrete crushing. The displacement of slab S2 at peak load reached $31.5 \mathrm{~mm}$. In this case the maximum vertical displacements ranging from $25 \mathrm{~mm}$ to $31.5 \mathrm{~mm}$ are located at the midspan of slab S2 for a reduced width of $100 \mathrm{~mm}$. Much less strain equal to $1.2 \%$ is observed outside of the slab central zone. The strain of $2.8 \%$ at the slab top surface occurred locally in the concrete crushing zone. The displacement of slab S3 at peak load reached the lowest value of $15.6 \mathrm{~mm}$. Local concrete crushing appeared at a load similar to that as in slab S2. The strains 
in this zone did not exceed $1.2 \%$. The maximum vertical displacements appeared at the midspan over a the width of $70 \mathrm{~mm}$. Values from 12 to $15.6 \mathrm{~mm}$ were reached.

S1
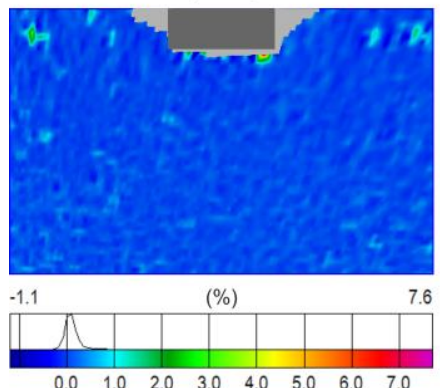

a half of the loaded steel plate

crushed the upper surface of the concrete slab

\section{S1}
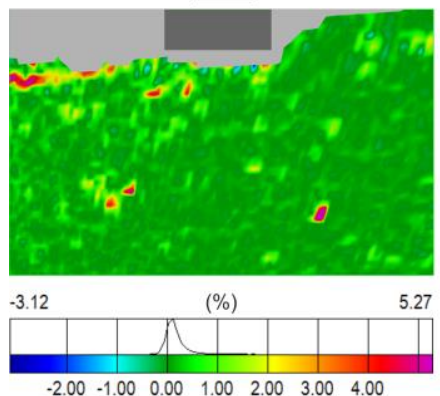

S2
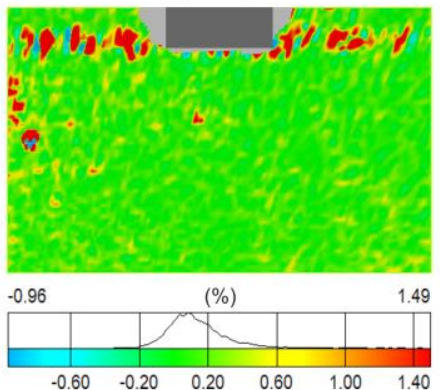

(a)

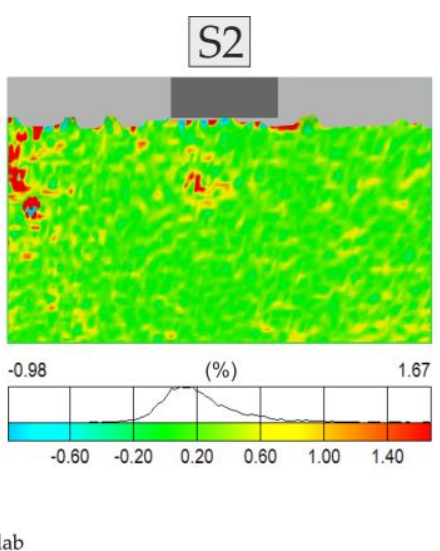

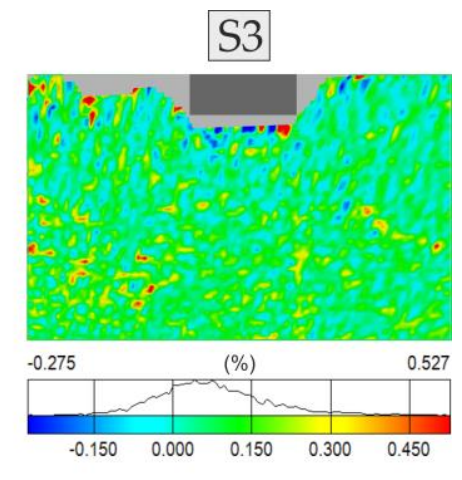

a half of the loaded steel plate

crushed the upper surface of the concrete slab

(b)

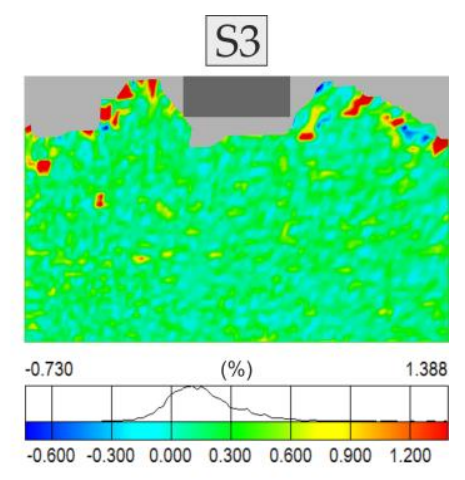

Figure 11. Strains at slab upper surface: (a) at peak load; (b) at last load.

The highest strain at the slab S1 top surface at the last load step was recorded at the distance of $100 \mathrm{~mm}$ from the centre. This value reached more than $2 \%$. The maximum displacement amounted to $33.6 \mathrm{~mm}$. The S2 slab strains reached up to $2 \%$. In this case the vertical displacements were over two-fold larger than in slab S1. The strains at the top surface of S3 slab with the highest content of hybrid fibre were higher than in slab S2. The observed fibre concrete crushing zones were smaller than in slabs S1 and S2. The vertical displacements for the S3 slab were significant and reached $56 \mathrm{~mm}$.

The major strains curves in the slabs upper surface with the location of cross-sections A-A, B-B and C-C are illustrated in Figure 12. The highest local strains in the S1, S2 and S3 slabs at the peak load are $1 \%, 5 \%$ and $2.5 \%$, respectively. It can be noted, that the most favourable deformation distribution was for the S2 slab. The presence of the fibres bridges the crushing surfaces and provides a restricting effect to the crushing area. This increases the possibility of redistribution of stresses in the crushing process and improves the ductility of the slab. 


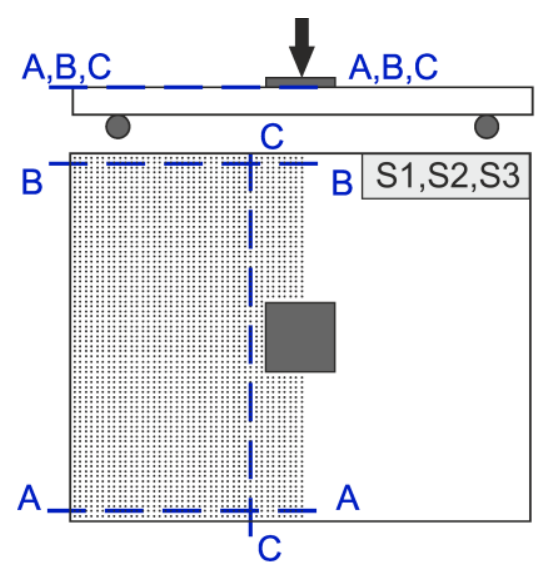

$\underline{B-B}$

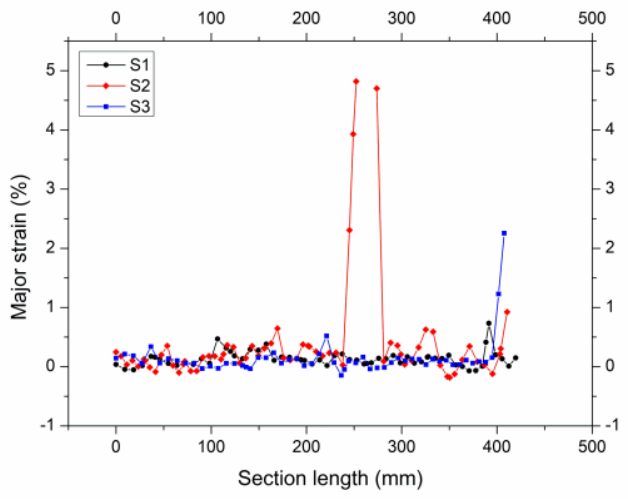

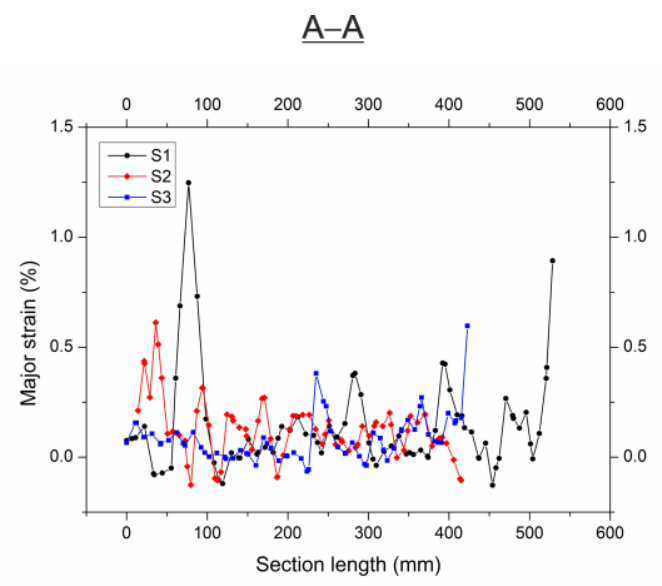

$\underline{\mathrm{C}-\mathrm{C}}$

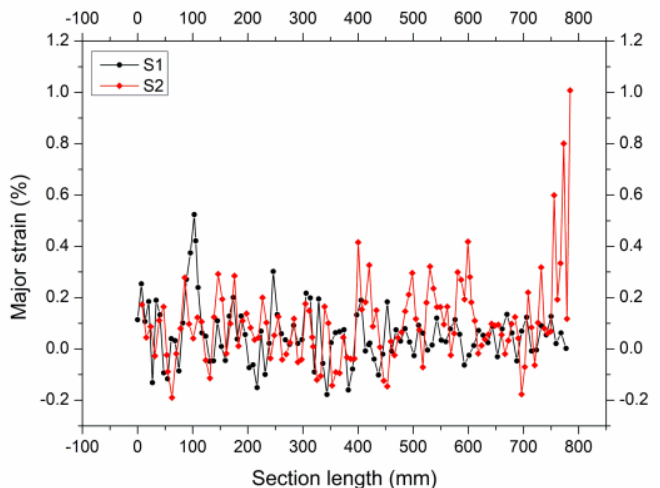

Figure 12. Major strains of slabs upper surface at peak load.

\subsection{Elastic and Inelastic Parameters of Slabs}

The elastic and inelastic parameters of the slabs are presented in Table 5. The initial stiffness, over-strength factor and ductility factor are defined and calculated according to [58].

Table 5. Slab parameters.

\begin{tabular}{ccccc}
\hline $\begin{array}{c}\text { Slab } \\
\text { Denotation }\end{array}$ & $\begin{array}{c}\text { Fibre Volume } \\
\text { Content (\%) }\end{array}$ & $\begin{array}{c}\text { Initial Stiffness } \\
\mathbf{( k N / m m )}\end{array}$ & $\begin{array}{c}\text { Over-Strength } \\
\text { Factor } \mathbf{( - )}\end{array}$ & $\begin{array}{c}\text { Ductility } \\
\text { Factor (-) }\end{array}$ \\
\hline S1 & - & 15.89 & 0.94 & 4.76 \\
S2 & 0.5 ST + 0.06 PP & 19.88 & 0.91 & 6.27 \\
S3 & 1 ST + 0.06 PP & 20.11 & 0.94 & 7.31 \\
\hline
\end{tabular}

It can be seen that the initial stiffness of the fibre slabs shows higher values compared to that of the reinforced concrete slabs. An increase in the initial stiffness of the fibre slabs is achieved by both an increase in the cracking load and a decrease in the corresponding deflection, which are effects of the addition of fibres.

The load-deflection curves for FRHPC slabs containing different combinations of fibres have been analysed by the post-crack strength method [61,62]. Using this method a load-deflection curve can be transformed into an equivalent flexural strength curve, the peak load is localized and the curve is divided into pre-peak and post-peak regions as illustrated in Figure 13.

The pre-peak and post-peak strengths at a ultimate deflection of $\delta_{m}$ for slabs with span $L$, depth $h$ and width $b$ are given by the following formulas: 


$$
\begin{gathered}
f_{\text {pre }}=\frac{E_{\text {pre }} L}{\delta_{\text {peak }} b h^{2}} \\
f_{\text {post }}=\frac{E_{\text {post }} L}{\left(\delta_{m}-\delta_{\text {peak }}\right) b h^{2}}
\end{gathered}
$$

The obtained results from the calculation are shown in Table 6.

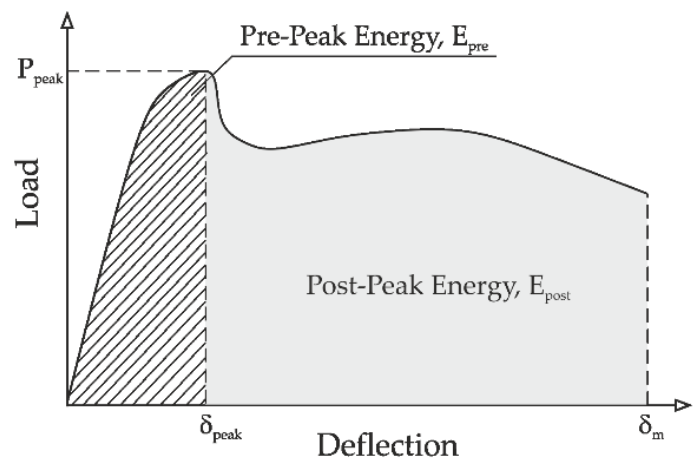

Figure 13. Pre-peak and post-peak strength analysis of fibre reinforced concrete slab.

\begin{tabular}{|c|c|c|c|c|c|c|}
\hline $\begin{array}{c}\text { Slab } \\
\text { Denotation }\end{array}$ & $\begin{array}{c}\text { Pre-Peak } \\
\text { Energy, } E_{\text {pre }} \\
(\mathrm{kN} \times \mathbf{m m})\end{array}$ & $\begin{array}{c}\text { Post-Peak } \\
\text { Energy, } E_{\text {post }} \\
(\mathrm{kN} \times \mathrm{mm})\end{array}$ & $\begin{array}{l}\text { Total Energy, } \\
E_{\text {total }}(\mathrm{kN} \times \\
\mathrm{mm})\end{array}$ & $\begin{array}{r}\text { Pre-Peak } \\
\text { Strength, } \\
f_{\text {pre }}(\mathrm{MPa})\end{array}$ & $\begin{array}{c}\text { Post-Peak } \\
\text { Strength, } \\
f_{\text {post }} \text { (MPa) }\end{array}$ & $\begin{array}{c}\text { Strength } \\
\text { Ratio, } \\
f_{\text {post }} / f_{\text {pre }}(-)\end{array}$ \\
\hline S1 & 1625.8 & 589.1 & 2214.9 & 14.5 & 14.9 & 1.03 \\
\hline S2 & 1949.7 & 2337.5 & 4287.2 & 17.5 & 13.6 & 0.78 \\
\hline S3 & 887.9 & 3097.7 & 3985.6 & 15.8 & 16.4 & 1.04 \\
\hline
\end{tabular}

Table 6. Energy and strength values for fibre reinforced high-performance concrete slabs.

It is observed that the high performance concrete slab without fibres showed the lowest pre-peak strength value. The pre-peak value increased significantly with the $0.5 \%$ addition of steel fibres and $0.06 \%$ addition of polypropylene fibres. On the other hand, the highest post-peak strength value is obtained by the slab containing the $1 \%$ steel fibres additions and $0.06 \%$ polypropylene fibres additions. The calculated parameters of all the slabs are compared in Figure 14.

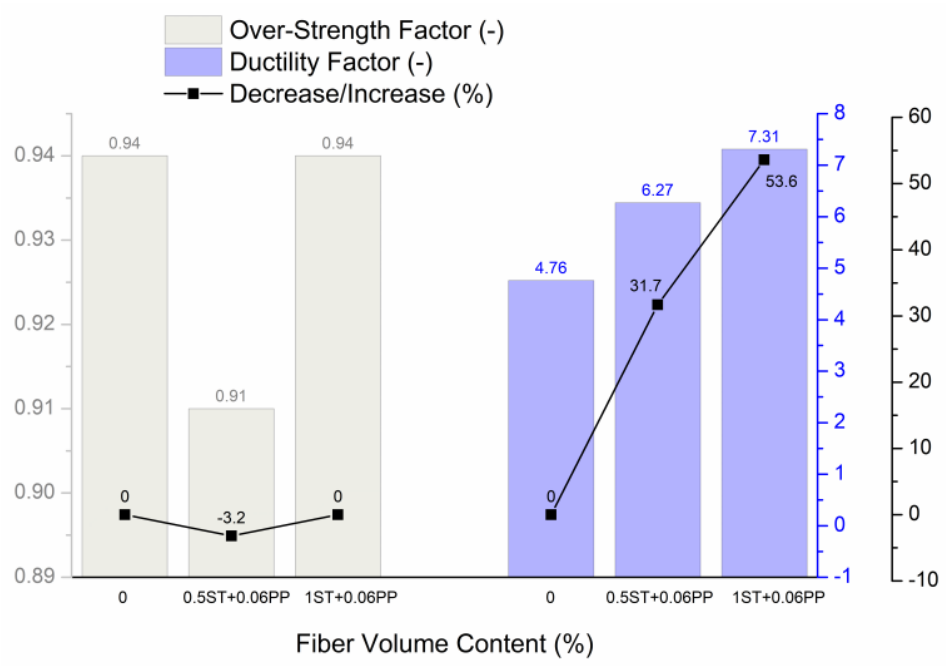

(a)

Figure 14. Cont. 


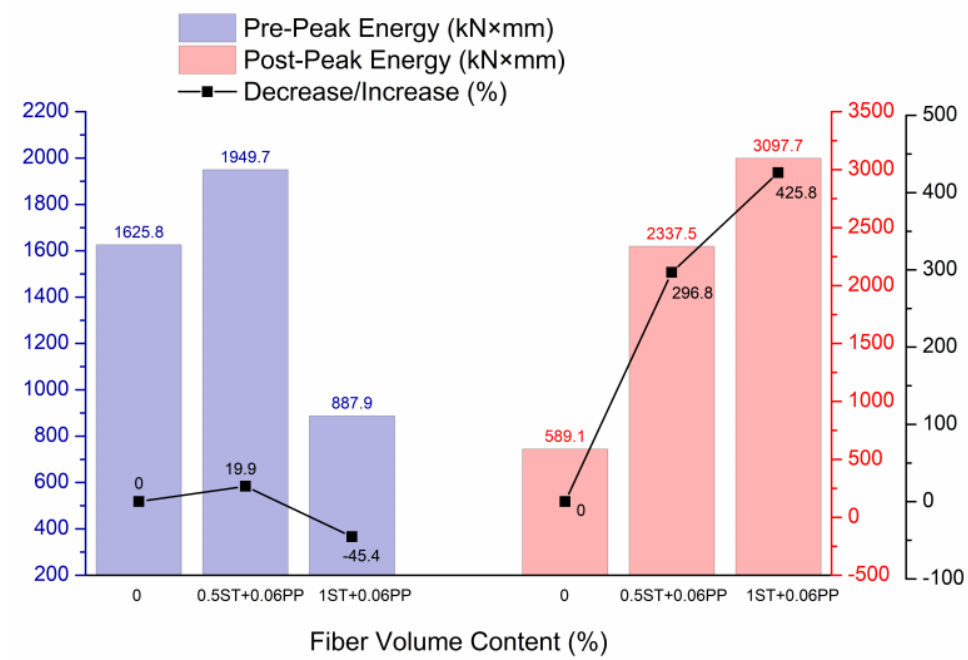

(b)

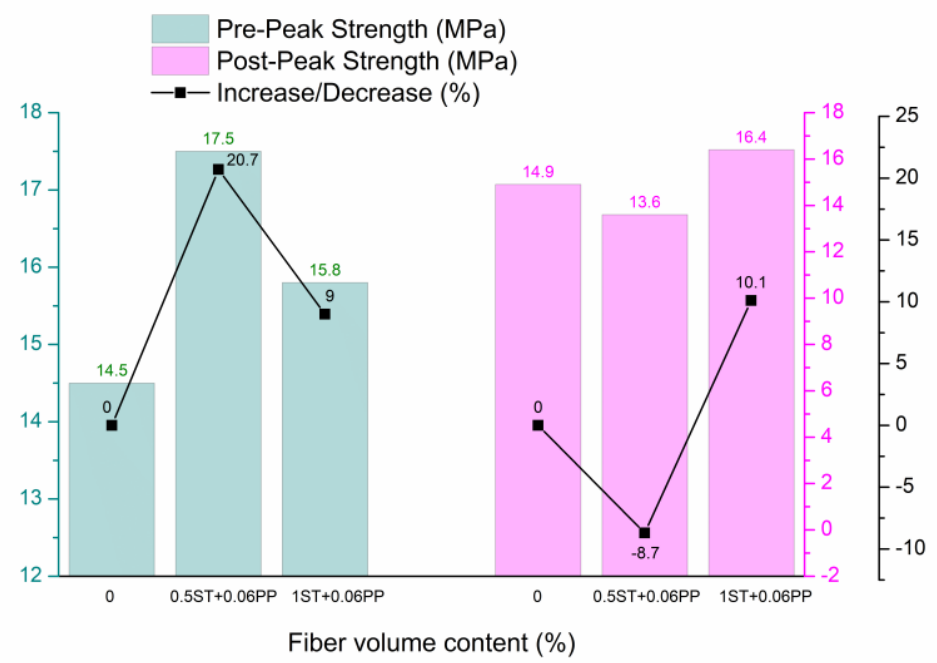

(c)

Figure 14. Comparison of slab (a) Over-strength and ductility factor (b) Pre- and post-peak energy (c) Pre- and post-peak strength.

Figure 14a reveals that the fibre concrete slabs have higher over-strength factor values compared to reinforced concrete slab S1. The slabs with the hybrid fibre contents obtained an increase in the failure deflection and in consequence, the ductility factors demonstrate the favourable impact of hybrid fibres on increasing the ductility. Increases of 31.7 and $53.6 \%$ in the ductility factors were found for slabs S2 and S3, respectively. The pre- and post-peak energies values are calculated by integrating the areas under the load-deflection curves and are displayed in Figure $14 \mathrm{~b}$ to compare the impact of fibre content on raising the post-peak energy absorption capacity of the slabs. It was noticed that the $45.4 \%$ decrease in the pre-peak energy for FRHPC belongs to slab S3, which confirmed the problems associated with obtaining a homogeneous fibre distribution at the highest content. As can be seen in Figure 14c, similar regularities were observed by comparing the pre- and post-peak strengths. The exception was slab S2 which obtained a slight decrease of $8.7 \%$ in the post-peak strength value due to the highest value of corresponding deflection.

\subsection{FEM Analysis}

Figure 15 presents the plots of the load-deflection responses and finite element results of the test slabs, while Table 7 compares the experimental results to the finite element ones. Generally, the 
midspan deflections at the cracking load and peak load of the test slabs and finite element solutions are in reasonably good agreement.

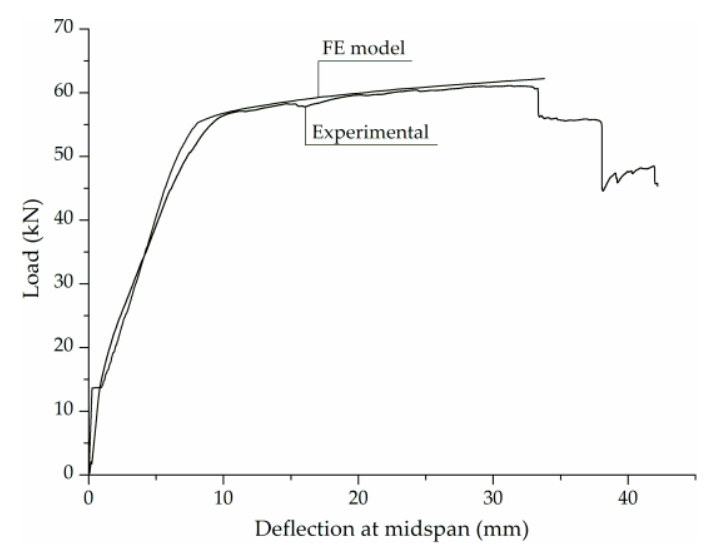

(a)

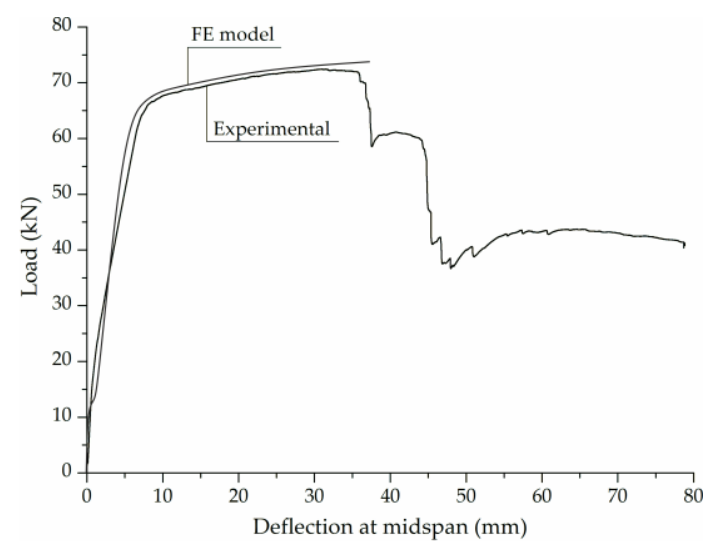

(b)

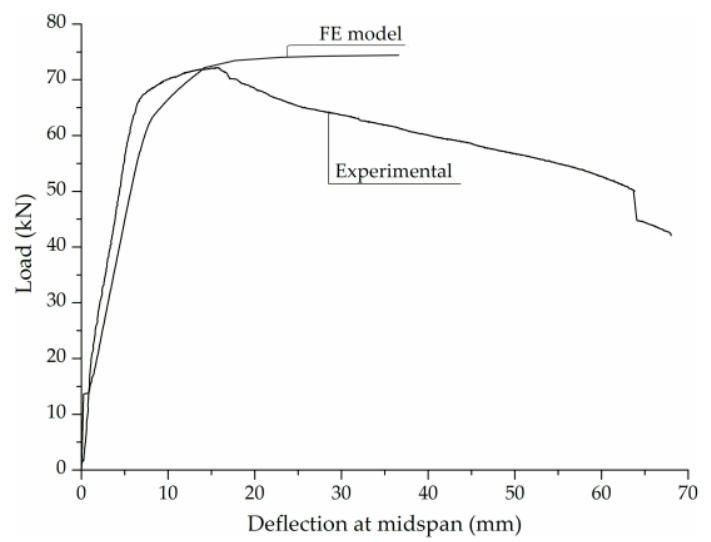

(c)

Figure 15. Experimental and FE load-deflection responses for slabs (a) S1; (b) S2; (c) S3.

Table 7. Comparison between experimental and finite element results.

\begin{tabular}{ccccccc}
\hline $\begin{array}{c}\text { Slab } \\
\text { Denotation }\end{array}$ & $\begin{array}{c}\text { Cracking } \\
\text { Load (kN) }\end{array}$ & $\begin{array}{c}\text { Deflection } \\
\text { at Cracking } \\
\text { Load }(\mathbf{m m})\end{array}$ & $\begin{array}{c}\text { Decrease in } \\
\text { Cracking } \\
\text { Load } \mathbf{( \% )}\end{array}$ & $\begin{array}{c}\text { Peak Load } \\
\mathbf{( k N )}\end{array}$ & $\begin{array}{c}\text { Deflection } \\
\text { at Peak } \\
\text { Load (mm) }\end{array}$ & $\begin{array}{c}\text { Increase in } \\
\text { Peak Load } \\
(\%)\end{array}$ \\
\hline \multicolumn{7}{c}{ Experimental/Finite Element Results } \\
\hline S1 & $14.3 / 13.6$ & $0.9 / 0.3$ & 5.0 & $61.1 / 62.2$ & $31.2 / 33.8$ & 1.8 \\
S2 & $15.9 / 12.1$ & $0.8 / 0.6$ & 23.9 & $72.4 / 73.6$ & $31.5 / 37.5$ & 1.7 \\
S3 & $18.1 / 13.4$ & $0.9 / 0.3$ & 25.9 & $72.2 / 74.3$ & $15.6 / 37.2$ & 2.9 \\
\hline
\end{tabular}

The finite element analyses load-deflection plots and the experimental data of the slabs coincide well, up to the peak load of the slabs, however, the compared load-deflection curves are slightly different. There are numerous factors that might cause this state. First of all, microcracks in the tested slabs can be created by drying shrinkage. In this analysis, microcracks in the concrete are not included in the FE models. Moreover, the perfect bond adopted in the finite element model between the concrete and steel reinforcement not realistic in the experimental slabs. What is more, the material softening after the peak load was not analysed in this model.

Figure 16 shows the experimental crack distributions as well as the maximum strain and crack locations for the last converged load step by nodal solution in the S1 and S3 slabs, respectively. The models of the side and bottom surfaces of slab S1 without fibres and slab S3 with the highest fibre content are used to demonstrate the crack patterns and strain contours. The principal tensile stresses 
arise in the $x$ direction in the slab bottom at the midspan. Flexural cracks appear perpendicular to the principal stress, when the concrete ultimate tensile strength is exceeded by the principal stress. In the concrete FE, the cracks, strains and stresses are calculated in the integration points. The first, second and third crack at an integration point are shown with red circle outline, green circle outline and blue circle outline, respectively. Crushing is shown with an octahedron outline and occurred when all principal stresses are compressive and lie outside the failure surface.
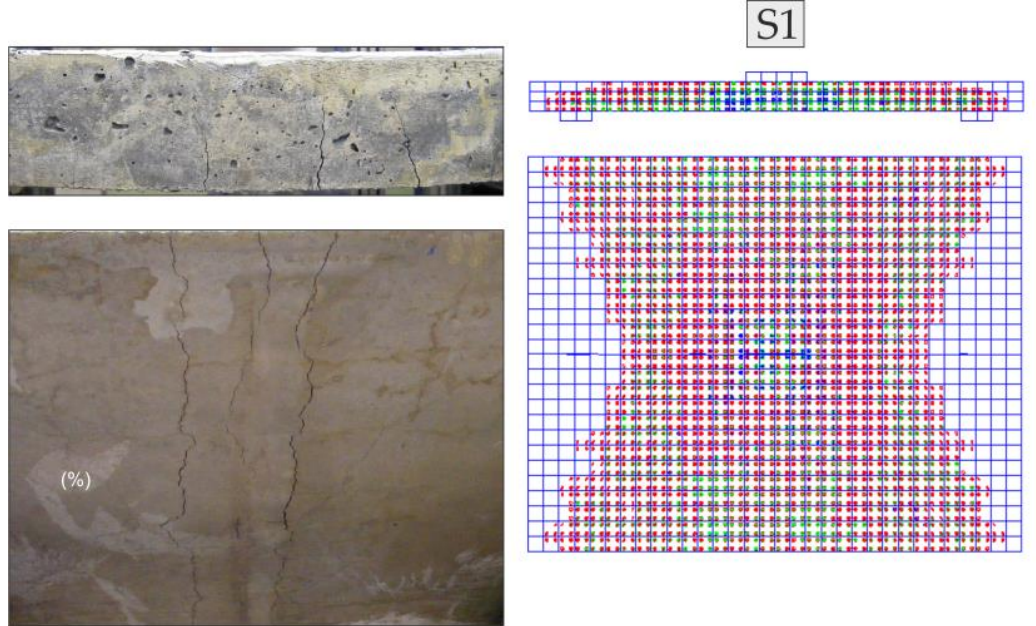

S1
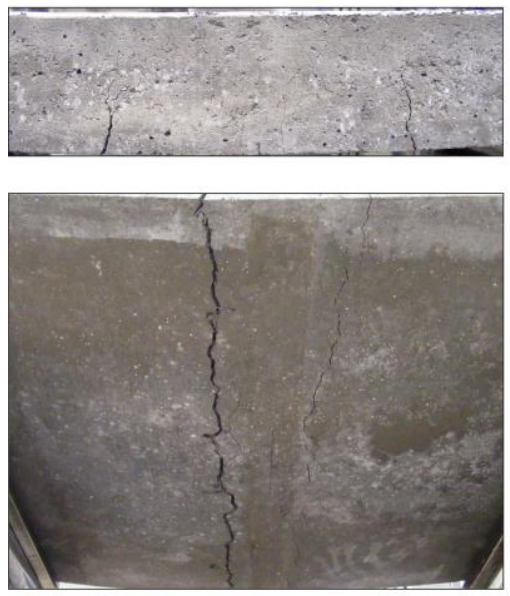

(a)
S3

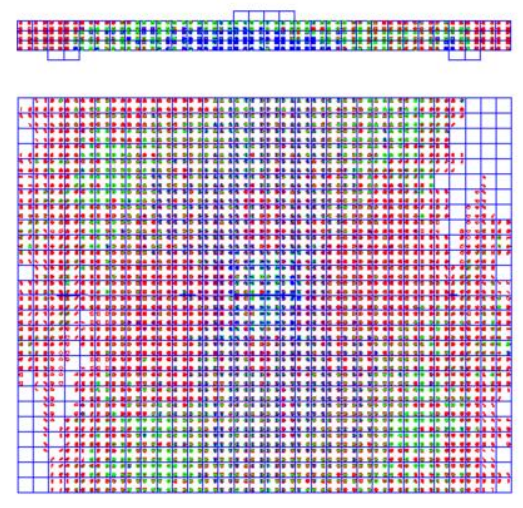

(b)

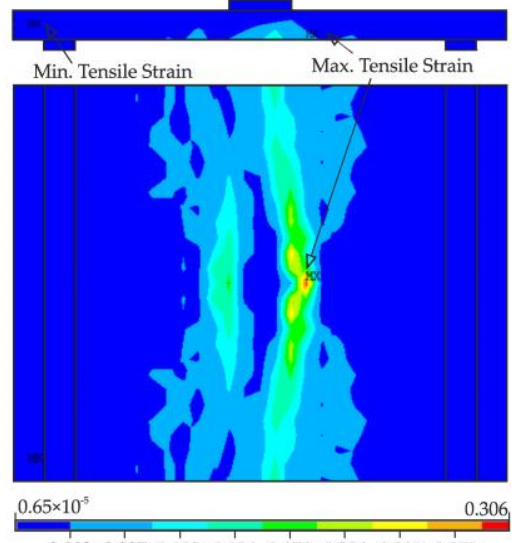

$\begin{array}{llllllllllll}0.003 & 0.007 & 0.102 & 0.136 & 0.170 & 0.204 & 0.238 & 0.272\end{array}$

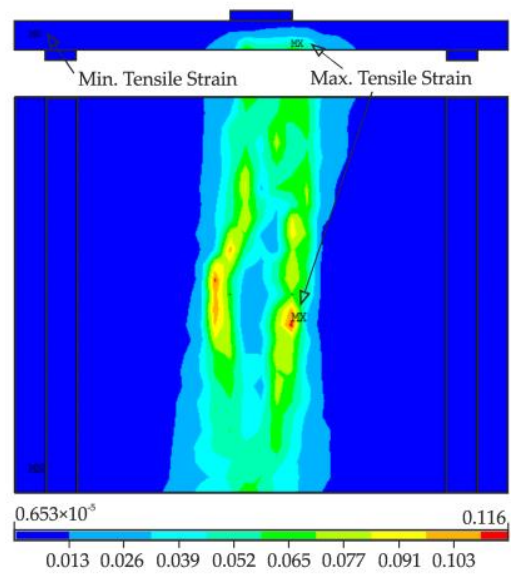

(c)

Figure 16. (a) Experimental and (b) FE crack distributions; (c) FE nodal solution of strains at last load step.

The number of cracked element of slab S3 that contains steel and polypropylene fibres of 1 and 0.06 vol.\% content, respectively is smaller than that of slab S1 without fibres obviously under the same load, thus it indicates directly that the steel fibre and polypropylene fibre can repress the spread and development of the cracks effectively in HPC slabs. The FEM simulations confirm that the hybrid fibre reinforcement influences the process of crack development in the slabs. The good compatibility of the strain distributions derived from the numerical analysis and the experimental crack patterns at the ultimate load step, presented in Figure 16, allow me to conclude that the applied numerical model for the FEM-simulation, is suitable for analysing hybrid fibre reinforced high-performance concrete slabs. 


\section{Conclusions}

The failure behaviour of hybrid fibre reinforced high-performance concrete slabs in experiments and finite element analysis are compared in this study. The experimental results confirmed the usefulness of steel and polypropylene fibres in improving elastic and inelastic properties such as the over-strength factor, ductility factor, pre- and post-peak energy, pre- and post-peak strength of high performance concrete slabs with web mesh. The ANSYS package was employed to carry out finite element failure analysis.

Upon assessing the experimental and finite element analysis results of the slabs, these conclusions can be drawn:

(1) Reinforced slab S1 without fibres exhibits similar behaviour to reinforced slab S2 with an 0.5 vol.\% content of steel fibres and 0.06 vol.\% content of polypropylene fibres. In contrast, with an increasing amount of steel fibre to 1 vol.\%, hybrid fibre slab S3 attains the same over-strength factor as slab S1.

(2) The load response of the slabs changes from brittle into elastic-plastic behaviour with increasing the amount of steel and polypropylene fibres.

(3) The presence of hybrid fibres in reinforced HPC slabs restricts the propagation of cracks better than the conventionally reinforced HPC slab and they allow more uniform cracking.

(4) FRHPC slabs have a more significant energy absorption capacity and a higher ductility factor than reinforced HPC slab without fibres. However, introducing a 1 vol.\% content of $\mathrm{L}=50 \mathrm{~mm}$ and $\mathrm{D}=1 \mathrm{~mm}$ hooked-end steel fibres and an $0.06 \mathrm{vol} \%$ content of $\mathrm{L}=12 \mathrm{~mm}$ polypropylene fibres into the reinforced HPC slab (S3) results in a lower total energy absorption capacity than slab S2 with half the amount of steel fibres.

(5) The inclusion of large hooked-end steel fibres and addition of polypropylene fibres increased the load-bearing capacity of HPC slabs considerably.

(6) The finite element analysis load-deflection curves of the slabs exhibit good conformity to the experimental curves. The failure property measurements taken during the experimental testing, the finite element analysis cracking and peak loads as well as the corresponding deflections match very well.

(7) The finite element analysis strain contours correspond to the test results.

Funding: This research was supported financially by the Polish Ministry of Science and Higher Education within statutory research project No. S/15/B/1/2018.

Acknowledgments: The financial support from the Polish Ministry of Science and Higher Education is greatly appreciated.

Conflicts of Interest: The author declares no conflicts of interest.

\section{References}

1. Sudin, R.; Swamy, N. Bamboo and wood fibre cement composites for sustainable infrastructure regeneration. J. Mater. Sci. 2006, 41, 6917-6924. [CrossRef]

2. Savastano, H.; Turner, A.; Mercer, C.; Soboyejo, W.O. Mechanical behavior of cement-based materials reinforced with sisal fibers. J. Mater. Sci. 2006, 41, 6938-6948. [CrossRef]

3. Glinicki, M.A. Testing of macro-fibres reinforced concrete for industrial floors. Cem. Wapno Beton 2008, 13, 184-195.

4. Farnam, Y.; Mohammadi, S.; Shekarchi, M. Experimental and numerical investigations of low velocity impact behavior of high-performance fiber-reinforced cement based composite. Int. J. Impact Eng. 2010, 37, 220-229. [CrossRef]

5. Sabet, F.A.; Libre, N.A.; Shekarchi, M. Mechanical and durability properties of self consolidating high performance concrete incorporating natural zeolite, silica fume and fly ash. Constr. Build. Mater. 2013, 44, 175-184. [CrossRef] 
6. Aïtcin, P.C. The durability characteristics of high performance concrete: A review. Cem. Concr. Compos. 2003, 25, 409-420. [CrossRef]

7. Afroughsabet, V.; Biolzi, L.; Ozbakkaloglu, T. High-performance fiber-reinforced concrete: A review. J. Mater. Sci. 2016, 51, 6517-6551. [CrossRef]

8. Banthia, N.; Gupta, R. Hybrid fiber reinforced concrete (HyFRC): Fiber synergy in high strength matrices. Mater. Struct. 2004, 37, 707-716. [CrossRef]

9. Cucchiara, C.; La Mendola, L.; Papia, M. Effectiveness of stirrups and steel fibres as shear reinforcement. Cem. Concr. Compos. 2004, 26, 777-786. [CrossRef]

10. Brandt, A.M. Fibre reinforced cement-based (FRC) composites after over 40 years of development in building and civil engineering. Compos. Struct. 2008, 86, 3-9. [CrossRef]

11. Chiaia, B.; Fantilli, A.P.; Vallini, P. Combining fiber-reinforced concrete with traditional reinforcement in tunnel linings. Eng. Struct. 2009, 31, 1600-1606. [CrossRef]

12. Di Prisco, M.; Plizzari, G.; Vandewalle, L. Fibre reinforced concrete: New design perspectives. Mater. Struct. 2009, 42, 1261-1281. [CrossRef]

13. Walraven, J.C. High performance fiber reinforced concrete: Progress in knowledge and design codes. Mater. Struct. 2009, 42, 1247-1260. [CrossRef]

14. Kuder, K.G.; Shah, S.P. Processing of high-performance fiber-reinforced cement-based composites. Constr. Build. Mater. 2010, 24, 181-186. [CrossRef]

15. Arisoy, B.; Wu, H.C. Material characteristics of high performance lightweight concrete reinforced with PVA. Constr. Build. Mater. 2008, 22, 635-645. [CrossRef]

16. Foster, S.J. The application of steel-fibres as concrete reinforcement in Australia: From material to structure. Mater. Struct. 2009, 42, 1209-1220. [CrossRef]

17. Özcan, D.M.; Bayraktar, A.; Şahin, A.; Haktanir, T.; Türker, T. Experimental and finite element analysis on the steel fiber-reinforced concrete (SFRC) beams ultimate behavior. Constr. Build. Mater. 2009, 23, 1064-1077. [CrossRef]

18. Kodur, V.K.R.; Cheng, F.P.; Wang, T.C.; Sultan, M.A. Effect of strength and fiber reinforcement on fire resistance of high-strength concrete columns. J. Struct. Eng.-ASCE 2003, 129, 253-259. [CrossRef]

19. Rashiddadash, P.; Ramezanianpour, A.A.; Mandikhani, M. Experimental investigation on flexural toughness of hybrid fiber reinforced concrete (HFRC) containing metakaolin and pumice. Constr. Build. Mater. 2014, 51, 313-320. [CrossRef]

20. Smarzewski, P.; Barnat-Hunek, D. Fracture properties of plain and steel-polypropylene-fiber-reinforced high-performance concrete. Mater. Tehnol. 2015, 49, 563-571. [CrossRef]

21. Barnat-Hunek, D.; Smarzewski, P. Influence of hydrophobisation on surface free energy of hybrid fiber reinforced ultra-high performance concrete. Constr. Build. Mater. 2016, 102, 367-377. [CrossRef]

22. Qian, C.X.; Stroeven, P. Development of hybrid polypropylene-steel fibre-reinforced concrete. Cem. Concr. Res. 2000, 30, 63-69. [CrossRef]

23. Fairbairn, E.M.R.; Toledo Filho, R.D.; Battista, R.C.; Brandao, J.H.; Rosa, J.I.; Formagini, S. Experimental and numerical analysis of UHPFRC plates and shells. In Measuring, Monitoring and Modeling Concrete Properties; Springer: Dordrecht, The Netherlands, 2006; pp. 49-58.

24. Dancygier, A.N.; Yankelevsky, D.Z.; Jaegermann, C. Response of high performance concrete plates to impact of non-deforming projectiles. Int. J. Impact Eng. 2007, 34, 1768-1779. [CrossRef]

25. Qiu, J.S. Study on Nonlinear Finite Element Analysis Method of Multi-ribbed Composite Slab Structure Containing Steel Fibers. Adv. Mater. Res. 2011, 250-253, 3975-3982. [CrossRef]

26. Fike, R.; Kodur, V. Enhancing the fire resistance of composite floor assemblies through the use of steel fiber reinforced concrete. Eng. Struct. 2011, 33, 2870-2878. [CrossRef]

27. Kodur, V.K.R.; Naser, M.; Pakala, P.; Varma, A. Modeling the response of composite beam-slab assemblies exposed to fire. J. Constr. Steel Res. 2013, 80, 163-173. [CrossRef]

28. Kodur, V.R.; Naser, M. Comparative Fire Performance of Composite Beam-slab Assemblies Casted with Plain and Steel Fiber Reinforced Concrete; Schaumann, F.P., Ed.; University of Hannover: Hannover, Germany, 2014.

29. Almusallam, T.H.; Siddiqui, N.A.; Iqbal, R.A.; Abbas, H. Response of hybrid-fiber reinforced concrete slabs to hard projectile impact. Int. J. Impact Eng. 2013, 58, 17-30. [CrossRef]

30. Thiagarajan, G.; Kadambi, A.V.; Robert, S.; Johnson, C.F. Experimental and finite element analysis of doubly reinforced concrete slabs subjected to blast loads. Int. J. Impact Eng. 2015, 75, 162-173. [CrossRef] 
31. ARAMIS v6.3: User Manual—Software; GOM mbH: Braunschweig, Germany, 2011.

32. ANSYS. ANSYS 14.5 Documentation; Swanson Analysis System: Canonsburg, PA, USA, 2013.

33. PN-EN 197-1. Cement. Composition, Specifications and Conformity Criteria for Common Cements. 2012. Available online: http:/ / sklep.pkn.pl/pn-en-197-1-2012e.html (accessed on 21 November 2018).

34. PN-B-19707:2013-10. Cement. Special Cement. Composition, Specifications and Conformity Criteria. 2013. Available online: http:/ / sklep.pkn.pl/pn-b-19707-2013-10p.html (accessed on 21 November 2018).

35. PN-EN 933-1. Tests for Geometrical Properties of Aggregates. Determination of Particle Size Distribution. Sieving Method. 2012. Available online: http://sklep.pkn.pl/pn-en-933-1-2012e.html (accessed on 21 November 2018).

36. PN-EN 12390-3. Testing Hardened Concrete. Compressive Strength of Test Specimens. 2011. Available online: http:/ / sklep.pkn.pl/pn-en-12390-3-2011p.html (accessed on 21 November 2018).

37. PN-EN 12390-6. Testing Hardened Concrete. Tensile Splitting Strength of Test Specimens. 2011. Available online: http:/ /sklep.pkn.pl/pn-en-12390-6-2011p.html (accessed on 21 November 2018).

38. PN-EN 12390-5. Testing Hardened Concrete. Flexural Strength of Test Specimens. 2011. Available online: http:/ / sklep.pkn.pl/pn-en-12390-5-2011p.html (accessed on 21 November 2018).

39. ASTM C469/C469M-14. Standard Test Method for Static Modulus of Elasticity and Poisson's Ratio of Concrete in Compression; ASTM International: West Conshohocken, PA, USA, 2014. [CrossRef]

40. Willam, K.J.; Warnke, K. Constitutive model for the triaxial behaviour of concrete. In Proceedings of the An International Association for Bridge and Structural Engineering (IABSE) Seminar on Concrete Structures Subjected to Triaxial Stresses, Part III-I, ISMES, Bergamo, Italy, 17 -19 May 1974.

41. Ottosen, N.S. Failure criterion for concrete. J. Eng. Mech. Div. J. 1977, 103, 527-535. [CrossRef]

42. Boswell, L.F.; Chen, Z. A general failure criterion for plain concrete. Int. J. Solids Struct. 1987, 23, 621-630. [CrossRef]

43. Han, D.J.; Chen, W.F. Constitutive Modeling in Analysis of Concrete Structures. J. Eng. Mech. 1987, 113, 577-593. [CrossRef]

44. Stolarski, A. Dynamic strength criterion for concrete. J. Eng. Mech. 2004, 130, 1428-1435. [CrossRef]

45. Jankowiak, T.; Łodygowski, T. Quasi-Static Failure Criteria for Concrete. Arch. Civ. Eng. 2010, 56, $123-154$. [CrossRef]

46. Zhang, J.; Zhang, Z.X.; Chen, C.Y. Yield criterion in plastic-damage models for concrete. Acta Mech. Solida Sin. 2010, 23, 220-230. [CrossRef]

47. ACI 363R-92. ACI Committee 363 Report. State-of-the-Art Report on High Strength Concrete; American Concrete Institute: Detroit, MI, USA, 1992.

48. Desayi, P.; Krishnan, S. Equation for the Stress-Strain Curve of Concrete. ACI J. Proc. 1964, 61, 345-350. [CrossRef]

49. Kamińska, M.E. High-strength concrete and steel interaction in RC members. Cem. Concr. Compos. 2002, 24, 281-295. [CrossRef]

50. Słowik, M.; Smarzewski, P. Study of the scale effect on diagonal crack propagation in concrete beams. Comp. Mater. Sci. 2012, 64, 216-220. [CrossRef]

51. Słowik, M.; Smarzewski, P. Numerical modeling of diagonal cracks in concrete beams. Arch. Civ. Eng. 2014, 60, 307-322. [CrossRef]

52. Smarzewski, P.; Stolarski, A. Numerical Analysis on the High-Strength Concrete Beams Ultimate Behaviour. In IOP Conference Series: Materials Science and Engineering; IOP Publishing: Bristol, UK, 2017; Volume 245, p. 032013.

53. Bažant, Z.P.; Cedolin, L. Finite Element Modeling of Crack Band Propagation. J. Struct. Eng. 1983, 109, 69-92. [CrossRef]

54. Crisfield, M.A. A fast incremental-iterative solution procedure that handles snap-through. Comput. Struct. 1981, 13, 55-62. [CrossRef]

55. Crisfield, M.A. An arc-length method including line searches and accelerations. Int. J. Numer. Methods Eng. 1983, 19, 1269-1289. [CrossRef]

56. Eggert, G.M.; Dawson, P.R.; Mathur, K.K. An adaptive descent method for nonlinear viscoplasticity. Int. J. Numer. Methods Eng. 1991, 31, 1031-1054. [CrossRef]

57. Smarzewski, P. Analysis of Failure Mechanics in Hybrid Fibre-Reinforced High-Performance Concrete Deep Beams with and without Openings. Materials 2019, 12, 101. [CrossRef] [PubMed] 
58. Smarzewski, P. Hybrid Fibres as Shear Reinforcement in High-Performance Concrete Beams with and without Openings. Appl. Sci. 2018, 8, 2070. [CrossRef]

59. Ferrara, L.; Ozyurt, N.; Di Prisco, M. High mechanical performance of fibre reinforced cementitious composites: The role of "casting-flow induced" fibre orientation. Mater. Struct. 2011, 44, 109-128. [CrossRef]

60. Kang, S.T.; Lee, B.Y.; Kim, J.-K.; Kim, Y.Y. The effect of fibre distribution characteristics on the flexural strength of steel fibre-reinforced ultra high strength concrete. Constr. Build. Mater. 2011, 25, 109-121. [CrossRef]

61. Banthia, N.; Sappakittipakorn, M. Toughness enhancement in steel fiber reinforced concrete through fiber hybridization. Cem. Concr. Res. 2007, 37, 1366-1372. [CrossRef]

62. Smarzewski, P. Flexural Toughness of High-Performance Concrete with Basalt and Polypropylene Short Fibres. Adv. Civ. Eng. 2018, 2018, 5024353. [CrossRef]

(C) 2019 by the author. Licensee MDPI, Basel, Switzerland. This article is an open access article distributed under the terms and conditions of the Creative Commons Attribution (CC BY) license (http:/ / creativecommons.org/licenses/by/4.0/). 